NOV $071996(2)$ ENGINEERING DATA TRANSMITTAL

Sta. 15

2. To: (Receiving organization)

Distribution

5. Proj./Prog./Dept./Div.:

B Plant

8. Originator Remarks:

Document issued for approval and release.

11. Receiver Rentarks:
3. From: (Originating Organization) Safety SAR Engineering

6. Cog. Engr.:

S. E. Chalk

4. Related EDT No.:

141803

7. Purchase Order No.:

$\mathrm{N} / \mathrm{A}$

9. Equip./Component No.:

$N / A$

10. System/Bldg./Facility:

B Plant

12. Major Assm. Dwg. No.:

$N / A$

13. Permit/Permit Application No.:

$N / A$

14. Required Response Date:

COB $7 / 12 / 96$

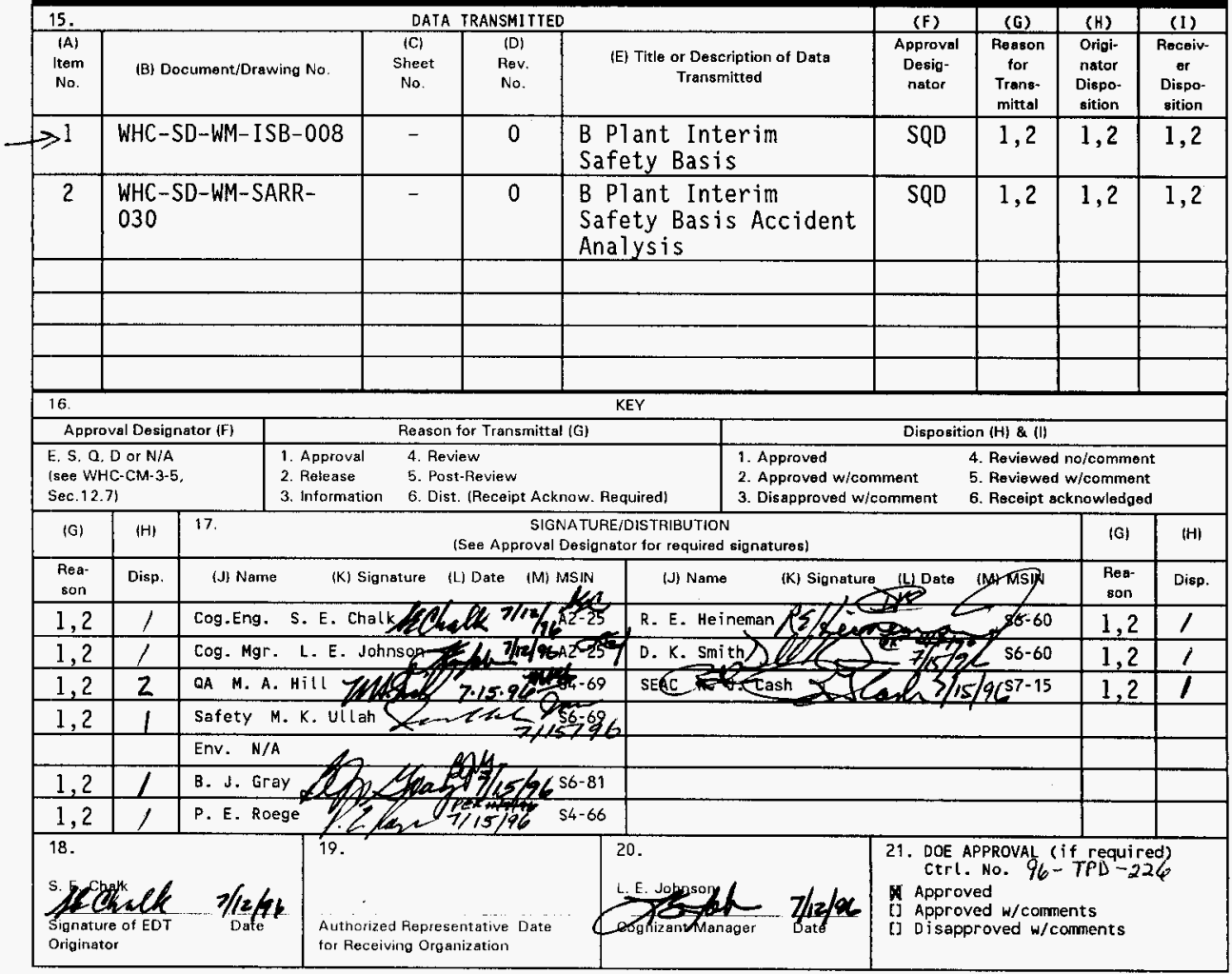

BD-7400-172-2 (04/94) GEF097 


\title{
B Plant Interim Safety Basis
}

\author{
S. E. Chalk
}

Westinghouse Hanford Company, Richland, WA 99352

U.S. Department of Energy Contract DE-ACO6-87RL10930

$\begin{array}{llll}\text { EDT/ECN: } & 600058 & \text { UC: } 510 \\ \text { Org Code: } & 403 & \text { Charge Code: } & \text { KN24F } \\ \text { B\&R Code: } & \text { EW3135090 } & \text { Total Pages: } 69\end{array}$

Key Words: B Plant, Safety Basis

Abstract: This interim safety basis (ISB-008) replaces the $B$ Plant Safety Analysis Report, WHC-SD-WM-SAR-013, Rev. 2 (WHC 1993a). ISB-008 uses existing accident analyses, modified existing accident analyses, and new accident analyses to prove that $B$ Plant remains within the safety envelope for transition, deactivation, standby, and shutdown activities. The analyses in ISB-008 are in accordance with the most current requirements for analytical approach, risk determination, and configuration management. This document and supporting accident analyses replace previous design-basis documents.

TRADEMARK DISCLAIMER. Reference herein to any specific comercial product, process, or service by trade name, trademark, manufacturer, or otherwise, does not necessarily constitute or imply its endorsement, recommendation, or favoring by the United States Government or any agency thereof or its contractors or subcontractors.

Printed in the United States of America. To obtain copies of this document, contact: UHC/BCS

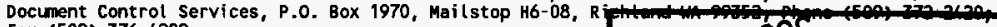
Fax (509) 376-4989.
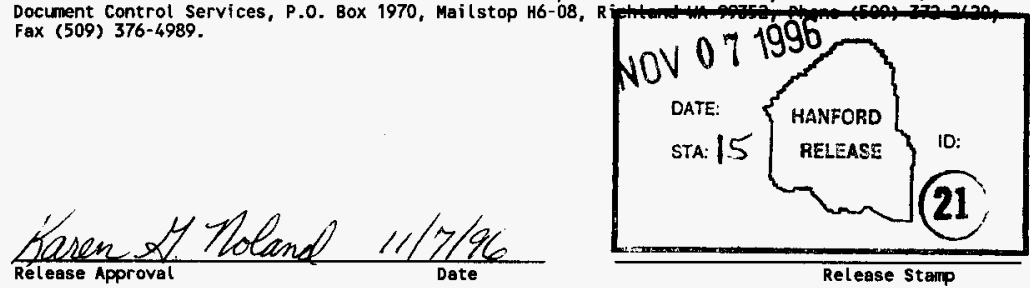

\section{Approved for Public Release}


WHC-SD-WM-ISB-008 REV 0

\section{B PLANT \\ INTERIM SAFETY BASIS}

WESTINGHOUSE HANFORD COMPANY

September 1996

For the U.S. Department of Energy Contract DE-AC06-87RL10930 
WHC-SD-WM-ISB-008 REV 0

This page intentionally left blank. 


\section{CONTENTS}

1.0 INTRODUCTION AND SUMMARY ................. 1 .1 1.1 CONCLUSION . . . . . . . . . . . . . . . . 1-1

2.0 FACILITY DESCRIPTION ....................... 2.1 THE B PLANT COMPLEX . . . . . . . . . . . . . 2-1

2.2 CURRENT PROCESSES . . . . . . . . . . . . . . 2-4

3.0 INTERIM SAFETY BASIS EVALUATION . . . . . . . . . . . . 3-1

3.1 HAZARDS ANALYSIS ................ . . 3-1

3.1.1 Hazard Categorization .............. 3-1

3.1.2 Hazard Identification and Bounding Conditions .... 3-1

3.1.3 Accident Analysis . . . . . . . . . . . 3-6

3.2 HAZARDS CONTROLS ...................... 3-10

3.2.1 Safety Class Structures, Systems, and Components . . . 3-11

3.2.2 Summary of Accident Analysis Assumptions ...... 3-22

3.2.3 Institutional Safety Programs . . . . . . . . 3-23

3.3 INTERIM SAFETY BASIS EVALUATION SUMMARY $\ldots \ldots \ldots . \ldots . \cdots 32$

4.0 CONFIGURATION CONTROLS SYSTEM . . . . . . . . . . . . . 4-1

4.1 CONFIGURATION MANAGEMENT . . . . . . . . . . . 4-1

4.1.1 B P1 ant Configuration Control and Verification . . . . 4-1

4.1.2 B Plant Facility/Process Monitor and

Control System Configuration Control ........ 4-1

4.1.3 Work Management .............. 4-1

4.1.4 Preparing 0perating Documents . . . . . . 4-4

4.1.5 B Plant Complex Writer's Guide

For Configuration Management ........... 4-4

4.1.6 Quality Assurance Program Plan

For Configuration Management ........... . 4-4

4.1.7 Sitewide Configuration Management ....... 4-5

4.2 QUALITY ASSURANCE ................. . . . . . .

4.2.1 Work Management . . . . . . . . . . . . 4-5

4.2.2 B Plant Maintenance . . . . . . . . 4-5

4.2.3 Quality Assurance Program P1an .......... 4-5

4.2.4 Sitewide Quality Assurance . . . . . . . . . . 4-6

4.3 PROCEDURE CONTROL . . . . . . . . . .

4.3.1 Review of New, Revised, and Procedure

4.3.2 Policy and Procedure Review ........... . . . . . . .

4.3.3 Preparing Operating Documents . . . . . . . 4-6

4.3.4 Conduct of Operations ........... 4-6

4.3.5 Quality Assurance Program Plan

For Procedure Control ...... . . . . . 4-7

4.3.6 B Plant Complex Writer's Guide

For Procedure Control . . . . . . . . . . . 4-7

4.3.7 Sitewide Procedure Controi $\ldots \ldots$ 4-7

4.4 UNREVIEWED SAFETY QUESTION PROCESS $\ldots \ldots \ldots$

4.4.1 Sitewide Unreviewed Safety Question Requirement ... 4-7 


\section{CONTENTS (Continued)}

5.0 REFERENCES . . . . . . . . . . . . . . . . . . 5-1

5.1 CODES AND REGULATIONS . . . . . . . . . . . . . . 5-1

5.2 DOCUMENTS . . . . . . . . . . . . . . . . . . . . . . .

5.3 WESTINGHOUSE HANFORD COMPANY CONTROLLED MANUALS . . . . . . . . 5-4

5.4 U.S. DEPARTMENT OF ENERGY ORDERS . . . . . . . . . . . . . . . 5-5

6.0 ACKNOWLEDGEMENTS ...................... 6- . . .

APPENDIX

A HAZARD CATEGORIZATION REPORT FOR B PLANT ........... A-1 


\section{LIST OF FIGURES}

2-1 B Plant Layout .................. 2- . . . . .

2-2 Chemical Storage Area Layout . . . . . . . . . . . 2-3

\section{LIST OF TABLES}

1-1 Onsite Risk Acceptance . . . . . . . . . . . . . 1-2

1-2 Estimated Onsite Dose Rate Reduction . . . . . . . . . 1-2

3-1 Severity. . . . . . . . . . . . . . 3-2

3-2 Probability. . . . . . . . . . . . . 3-2

3-3 B Plant Accident Scenarios Requiring Further Examination .... 3-3

3-4 Seismically Induced Hazards . . . . . . . . . . . . . 3-5

3-5 Seismic Accident Scenarios . . . . . . . . . . . . 3-6

3-6 Radiological Risk Acceptance Guidelines . . . . . . . . . 3-6

3-7 Toxicological Risk Acceptance Guidelines . . . . . . . . . . 3-6

3-8 Accidents Identified for Examination . . . . . . . . 3-8

3-9 Seismic Qualification Facility Safety Classifications . . . . . 3-11

3-10 Summary of Assumed Failures for 0.12g Design-Basis Earthquake . . . 3-22

3-11 Administrative and Programmatic Controls . . . . . . . . . . 3-24

4-1 Configuration Control Systems . . . . . . . . . . . . 4-2 


\section{LIST OF TERMS}

$\begin{array}{ll}\text { ALARA } & \text { as low as reasonably achievable } \\ \text { AMU } & \text { aqueous makeup unit } \\ \text { D\&D } & \text { decontamination and decommissioning } \\ \text { DBA } & \text { design-basis ashfal1 } \\ \text { DBE } & \text { design-basis earthquake } \\ \text { DOE } & \text { U.S. Department of Energy } \\ \text { ECA } & \text { environmental compliance assessment } \\ \text { HEPA } & \text { high-efficiency particulate air (filter) } \\ \text { HNO3 } & \text { nitric acid } \\ \text { HRHE } & \text { Hanford (Site) Regional Historical Earthquake } \\ \text { IOSR } & \text { interim operational safety requirements } \\ \text { ISB } & \text { interim safety basis } \\ \text { NaOH } & \text { sodium hydroxide } \\ \text { PHA } & \text { preliminary hazards analysis } \\ \text { SSE } & \text { safe shutdown earthquake } \\ \text { TSR } & \text { technical safety requirements } \\ \text { USQ } & \text { unreviewed safety question } \\ \text { WESF } & \text { Waste Encapsulation and Storage Facility } \\ \text { WHC } & \text { Westinghouse Hanford Company }\end{array}$




\subsection{INTRODUCTION AND SUMMARY}

This interim safety basis (ISB-008) replaces the B Plant Safety Analysis Report, WHC-SD-WM-SAR-013, Rev. 2 (WHC 1993a). ISB-008 uses existing accident analyses, modified existing accident analyses, and new accident analyses to prove that $B$ Plant remains within the safety envelope for transition, deactivation, standby, and shutdown activities. The analyses in ISB-008 are in accordance with the most current requirements for analytical approach, risk determination, and configuration management. This document and supporting accident analyses replace previous design-basis documents.

The last B Plant process mission was completed in 1985. Currently, the facility is undergoing preparations for transition to decontamination and decommissioning (D\&D). ISB-008 governs B Plant operations through this transition period. Currently, B Plant supports Waste Encapsulation and Storage Facility (WESF) Operations and some B Plant systems could support safety functions within WESF; however, these safety functions will be identified in the WESF ISB because WESF will be isolated from B Plant before the facility is turned over to D\&D.

B Plant transition activities are described in $B$ Plant Cleanout and Stabilization Update, WHC-SD-WM-PRS-014, Rev. O (WHC 1994a). These activities include removal of the remaining organic and aqueous inventories in the process cells. Requirements governing the inventory removal are not available at this time; however, it is anticipated that the organics may be required to undergo further processing (i.e., washing).

ISB-008 addresses the B Plant safety issues regarding routine transfers between canyon tanks and tank farms. Other possible methods of transfer, or transport of radioactive and hazardous material, are examined on a case-by-case basis. The safety analysis in this document is addressed through the following approach.

- B Plant hazards are identified and the facility is categorized.

- A preliminary hazards analysis (PHA) identifies accident scenarios that need to be addressed through the accident analysis.

- The accident analysis addresses the concerns identified in the PHA and any additional accident scenarios that were identified as safety concerns.

The B Plant configuration control system components addressed include configuration management, quality assurance, procedure control, and the unreviewed safety question process.

\subsection{CONCLUSION}

ISB-008 determines that the $B$ P1ant Complex remains within the safety envelope for transition, deactivation, standby, and shutdown activities, with the exception of the safety concerns stated in this ISB-008. The accident scenarios of concern are the design-basis earthquake (DBE) of $0.12 \mathrm{~g}$, the DBE 
with a stack collapse on the filter building, and the DBE with (organic or aqueous) solution spray leak. B Plant remains within the offsite risk acceptance guidelines during these accident scenarios; however, the onsite doses are above the risk acceptance guidelines.

Based on the proposed $\mathrm{B}$ Plant hazard reduction initiative, a timetable for a set of cleanup activities is developed. These actions impact the onsite dose rate from the DBE.

Based on the reduction in dose rate for the DBE, the possibility of exceeding the risk acceptance guidelines (WHC-CM-4-46, Nonreactor Facility Safety Analysis) is reduced over the next three and one-half years, while B Plant continues with the cleanout and stabilization program (Tables 1-1 and 1-2). This conclusion is based on the analyses performed in $B$ Plant Interim Safety Basis Accident Analysis, WHC-SD-WM-SARR-030, Rev. 0 (WHC 1996a).

Table 1-1. Onsite Risk Acceptance.

\begin{tabular}{|l|c|c|c|}
\hline \multicolumn{1}{|c|}{ Scenerio } & $\begin{array}{c}\text { Frequency (per } \\
\text { year) }\end{array}$ & EDE (Rem) & EDE/RAG (Rem) \\
\hline DBE & 1 E-03 & 28.39 & 25 \\
\hline DBE with solution spray leak & 2.3 E-06 & 29.6 & 100 \\
\hline DBA & 2.08 E-03 & 15.06 & 25 \\
\hline
\end{tabular}

DBA = Design-basis ashfall.

$D B E=$ Design-basis earthquake.

$E D E$ = Effective dose equivalent.

RAG = Risk acceptance guideline.

Table 1-2. Estimated Onsite Dose Rate Reduction.

\begin{tabular}{|c|c|c|c|}
\hline Activity & Basel ine & $\begin{array}{l}\text { TRemoval of } \\
\text { organics }\end{array}$ & $\begin{array}{c}\text { Cenyon decontamination and aqueous } \\
\text { solution removal }\end{array}$ \\
\hline Date & $4 / 95$ & $6 / 97$ & $9 / 98$ \\
\hline $\begin{array}{l}\text { DBE } \\
(1 \mathrm{E}-03 / \mathrm{yr})\end{array}$ & -- & $-\cdot$ & 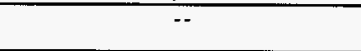 \\
\hline EDE/RAG(rem) & $28.39 / 25$ & $11.69 / 25$ & $2.0 / 25$ \\
\hline $\begin{array}{l}\text { DBE with solution } \\
\text { spray leak } \\
(2.6 \text { E-06/yr) }\end{array}$ & -- & -- & -- \\
\hline EDE/RAG (rem) & $29.60 / 100$ & $12.90 / 100$ & n/a (organic and aqueous solution \\
\hline
\end{tabular}

Doses without organic fire or temperature degradation of filters, but includes stack collapse on B Filter.

assumed.

Doses without hydrogen explosion. A 50\% reduction in dose from canyon contamination is

$D B E=$ Design-besis earthquake. $E D E=$ Effective dose equivalent.

RAG = Risk acceptance guideline. $n / a=$ not applicable. 


\subsection{FACILITY DESCRIPTION}

B Plant was built in 1945 and is currently operated by Westinghouse Hanford Company (WHC). B Plant processed large quantities (>100 MC $i$ ) of ${ }^{137} \mathrm{Cs}$ and ${ }^{90} \mathrm{Sr}$. Residual radioactive contamination from this processing is located throughout the facility in various forms.

\subsection{THE B PLANT COMPLEX}

The B Plant Complex consists of several buildings and support facilities in the northwest corner of the 200 East Area. A layout of B Plant is provided in Figure 2-1. B Plant was designed to chemically process spent nuclear fuels. The B Plant Canyon structure, 221-B, is uniquely suited for radioactive chemical processing. The 221-B Canyon is 247-m long, 23.5-m high, and has a cross-section width of $20 \mathrm{~m}$. A bridge crane (40.82 $\mathrm{t}$ capacity) is operated remotely to perform all mechanical work in the process area and in other high-radiation canyon areas. Radioactive containment and confinement features are incorporated in the various facilities and support systems to protect plant personnel and the public from excessive radiation exposures. The 221-B Canyon structure separates clean working areas from highlycontaminated process areas with heavy concrete shielding. Figure 2-2 provides the 221-B Chemical Storage Area Layout.

The 221-B Canyon deck elevation is 217-m above mean sea level and is 92-m above the underlying water table at $124-\mathrm{m}$ mean sea level and $77-\mathrm{m}$ above the elevation of the Columbia River at $139.6-\mathrm{m}$ mean sea level. The river makes its closest approach at 11.3-km northwest of the B Plant Complex.

The 221-B Canyon process area consists of 40 cells that are accessible from the crane and are covered with removable concrete shielding blocks. Most of the cells contain contaminated equipment that can be removed remotely by the crane. The hot (radioactive) pipe trench, located on the south side of the 221-B Canyon above the wind tunnel, is used for transferring radioactive process liquids and chemicals between the process cells. The hot pipe trench is also covered with removable concrete shielding. Three service galleries run the full length of the building and are located under the craneway. The electrical gallery, pipe gallery, and operating gallery provide space for noncontaminated electric, instrument, and process canyon equipment. The B Plant Complex is described in greater detail in B Plant Facility Description, WHC-SD-WM-TM-004, Rev. 0 (WHC 1994b), which details the following:

- Confinement system

- Containment barrier

- Ventilation system

- High-efficiency particulate air (HEPA) filter system

- Sand filter

- 291-B-1 Stack and monitoring system

- Primary containment

- Liquid handling

- Utilities and fire protection system. 


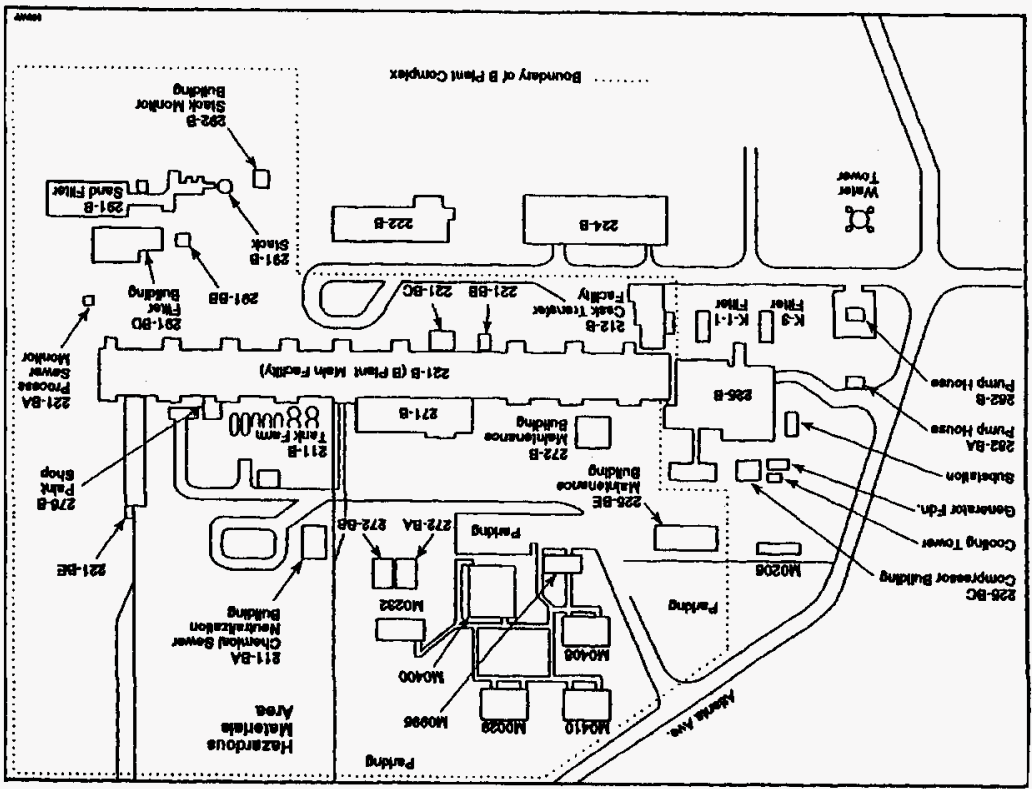

-qnoke $\rceil$ que Ld $g \quad \cdot[-\tau$ วun6!J 
WHC-SD-WM-ISB-008 REV 0

Figure 2-2. Chemical Storage Area Layout.

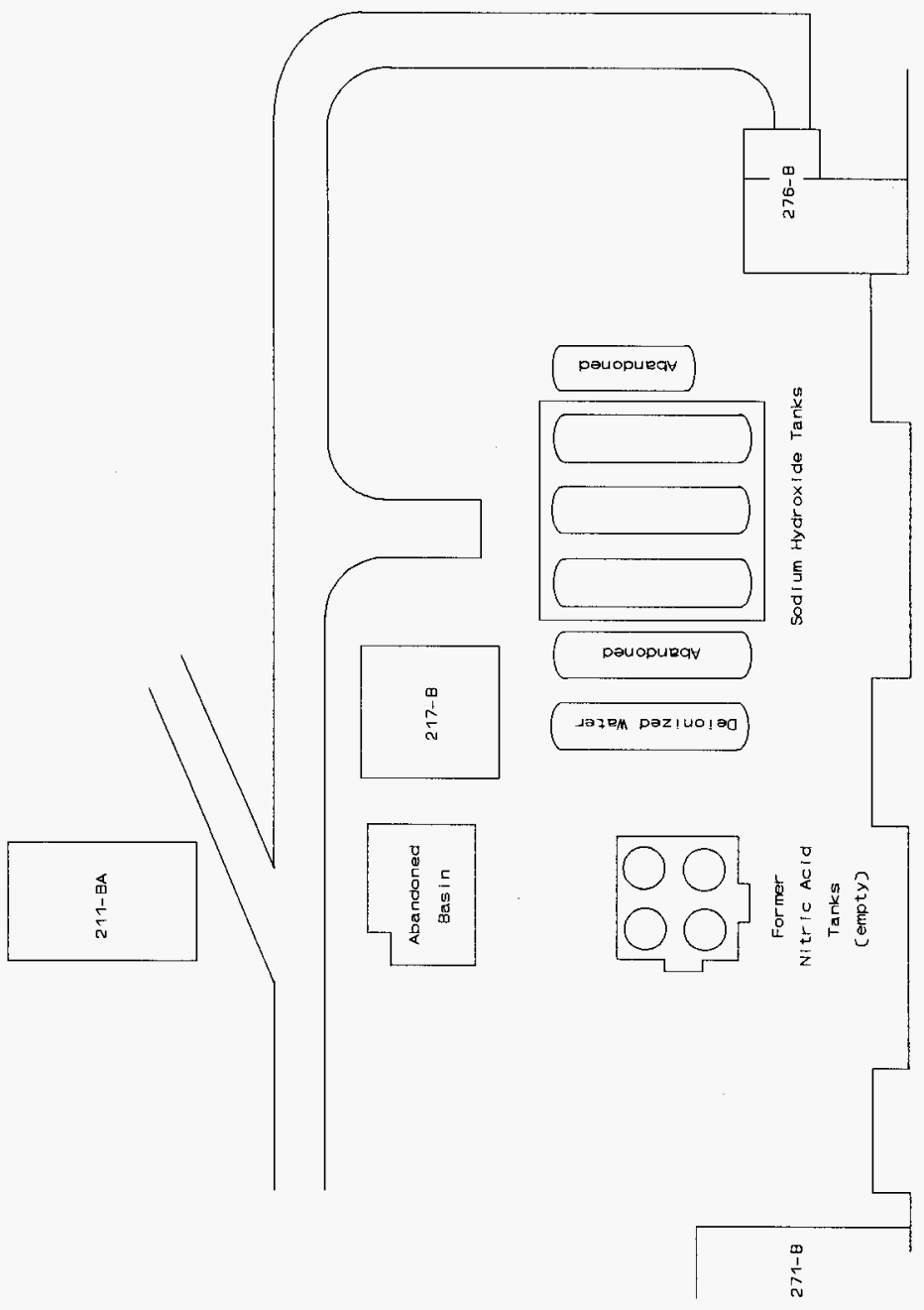




\subsection{CURRENT PROCESSES}

B Plant is currently transitioning to long-term surveillance and maintenance to monitor any residual contamination and to ensure the health and safety of personnel before the facility enters the D\&D phase. During this transition, segments of the facility will also undergo deactivation in preparation for D\&D. Deactivation and WESF support activities are the only active B Plant operational processes.

The deactivation activities are defined in WHC-SD-WM-PRS-014 (WHC 1994a), which documents the progress and remaining tasks for facility cleanup and includes the following:

- Canyon work area decontamination

- Radioactive liquid removal

- Equipment deactivation

- Characterization and stabilization of source terms from contamination (e.g., HEPA filters, residual concrete, and equipment).

B Plant will continue to perform some operational activities and support WESF. These activities include the following.

- Storing organic and the associated aqueous phase and performing decontamination with caustic washes.

- Storing and transferring to Tank Farms the B Plant and WESF low-level waste.

- Maintaining and monitoring the liquid and air effluents and maintaining the HEPA filters and associated water seals.

- General plant maintenance.

The 224-B Building is a storage facility that housed tanks containing plutonium solution. The tanks are now empty except for residual contamination. The tanks are tied to the $B$ Plant ventilation system and passively vent through the B Plant filters. Because the tanks are empty, except for residual contamination, venting is no longer required by 224-B.

Several systems must remain operational to support the adjacent WESF Complex and its radioactive inventory of strontium and cesium capsules. WESF will be isolated from B Plant before the facility is turned over to D\&D. 


\subsection{INTERIM SAFETY BASIS EVALUATION}

This section evaluates the interim B Plant hazards and identifies the controls needed to limit the risks from the hazards and ensure safe facility operation.

\subsection{HAZARDS ANALYSIS} functions.

The B Plant Facility interim hazards analysis performs the following four

1. Identifies or designates the facility hazard class, in accordance with WHC-CM-4-46, Section 4.0, "Determining and Documenting Facility Hazard Category."

2. Identifies the potential hazardous conditions and associated potential accident scenarios (including natural phenomena events) of current and proposed facility activities.

3. Provides consequence analyses of the significant accident scenarios that have the potential for exceeding acceptance criteria for the public and onsite worker. Analyses include the identification of any structures, systems, components, or operator actions utilized to control or mitigate consequences.

4. Provides qualitative or quantitative evaluation of risk for the accident scenarios.

\subsubsection{Hazard Categorization}

B Plant is classified as Hazard Category 2, in accordance with Hazard Categorization and Accident Analys is Techniques for Compliance With DOE Order 5480.23, DOE-STD-1027-92 (DOE 1992a), and DOE Order 5480.23, Nuclear Safety Analysis Reports. The hazard categorization analysis is included in Appendix $A$. The hazard categorization is identified by determining the ratio of the total quantity of each specific facility radionuclide to the Hazard Category 2 threshold quantities for the identical radionuclide provided in the standard. The ratio quantities are summed, once the individual isotopic ratios are established. If the total of the ratios exceeds one, then the facility is classified as a Hazard Category 2 nuclear facility.

\subsubsection{Hazard Identification and Bounding Conditions}

B Plant Preliminary Hazards Analysis, WHC-SD-WM-PHA-008, Rev. 0 (WHC 1993b), identified numerous hazards from which the accident scenarios requiring further examination are developed. Accident scenario examination is based on qualitative judgement, which determines the severity and frequency of postulated releases. Those accident scenarios identified as anticipated or 
unlikely with Severity Level I, II, and III require further examination (Table 3-1 and 3-2 provide definitions). Extremely unlikely scenarios with Severity Level I and II also warrant additional examination.

Table 3-1. Severity.

\begin{tabular}{|c|l|}
\hline $\begin{array}{c}\text { Severity } \\
\text { categories }\end{array}$ & \multicolumn{1}{|c|}{ Consequences to the public, personnel, or environment } \\
\hline I & $\begin{array}{l}\text { May cause deaths onsite or loss of the facility/operation, major injuries or illness } \\
\text { offsite, radiation exposure to offsi te individuals in excess of annul limits, or severe } \\
\text { impact on the environment. }\end{array}$ \\
\hline II & $\begin{array}{l}\text { May cause severe injuries or severe occupational illness onsite, exposure to ons ite } \\
\text { individuals in excess of annul limits, major damage to a facility/operation, minor } \\
\text { illness or injury offsite, exposure to offsi te individuals to radiation below annual } \\
\text { limits, or major impact on the environment. }\end{array}$ \\
\hline III & $\begin{array}{l}\text { May cause minor injury or minor occupational illness onsite, or exposure of onsite } \\
\text { individuals to radiation bel ow anmul limits, negligible impact offsite, or minor impact } \\
\text { on the environment. }\end{array}$ \\
\hline IV & $\begin{array}{l}\text { Will not result in injury, occupational illiness, or exposure onsite or offsite, or result } \\
\text { in a significant impact on the environment. }\end{array}$ \\
\hline
\end{tabular}

Table 3-2. Probability.

\begin{tabular}{|l|l|c|}
\hline \multicolumn{1}{|c|}{ Probability category } & \multicolumn{1}{|c|}{ Category description } & Frequency \\
\hline Anticipated & $\begin{array}{l}\text { An sbnormal event that is expected to occur once or more } \\
\text { during the lifet ime of the facility (e.g., small radioactive } \\
\text { materials spills, small fires) }\end{array}$ & $10^{-2}$ to 1 \\
\hline Unlikely & $\begin{array}{l}\text { Individually, the condition is not expected to occur during } \\
\text { plant lifetime, but collectively, events in this category may } \\
\text { occur several times. }\end{array}$ & $10^{-4}$ to $10^{-2}$ \\
\hline Extremely Unl ikely & $\begin{array}{l}\text { Extremely low probability conditions that are not expected } \\
\text { during the plant lifet ime but that represent extreme or } \\
\text { limiting cases of faults ident if ied as possible. This } \\
\text { category includes design-basis accidents. }\end{array}$ & $10^{-6}$ to $10^{-4}$ \\
\hline Incredible & Accident for wich no credible scenario can be identified. & $<10^{-6}$ \\
\hline
\end{tabular}

In summary, the PHA is used as a tool by the analyst to focus attention on scenarios that represent the greatest risk.

The breakdown of scenarios requiring further examination can be made on a severity basis.

- For Severity Level I and II - Only Anticipated, Unlikely, and Extremely Unlikely accident probabilities will be evaluated.

- For Severity III - Only Anticipated, and Unlikely accident probabilities will be evaluated.

Table 3-3 lists the hazards and subsequent accident scenarios requiring further examination, based on the determined severity and frequency criteria. The Accident Analysis further examines the hazards and subsequent accident scenarios specifically associated with the seismic event. Table 3-4 presents all of the potentially seismically induced hazards. Table 3.5 presents the list of seismically induced hazards analyzed. The seismic events presented below are analyzed further in the Accident Analysis. 
Table 3-3. B Plant Accident Scenarios Requiring Further Examination. (2 sheets)

\begin{tabular}{|c|c|c|c|}
\hline Facility & Hazard & Accident & Severity level \\
\hline General facility & Seismic event & Multiple failures & 1/EU \\
\hline General facility & High winds & Multiple failures & 11/EU \\
\hline 221-B: organic process cells & Organic vapors & Exposure to vapors/fire & $11 / \mathrm{U}$ \\
\hline 221-B: organic process cells & Seismic & Tank damage & $11 / \mathrm{U}$ \\
\hline 221-B: organic process cells & Red oil & Explosion & $\begin{array}{l}\text { 111/1 } \\
\text { This accident does not meet the } \\
\text { selection criteria; however, } \\
\text { because of the overall concern for } \\
\text { red oil throughout the bOE Complex, } \\
\text { this accident scenario will be } \\
\text { examined. }\end{array}$ \\
\hline 221-B: tank TK-10-1 & Red oil & Explosion & $\begin{array}{l}\text { III/I } \\
\text { This accident does not meet the } \\
\text { selection criteria; however, } \\
\text { because of the overall concern for } \\
\text { red oil throughout the doE COmplex, } \\
\text { this accident scenario will be } \\
\text { examined. }\end{array}$ \\
\hline 221-B: inactive process cells & Hydrogen accumulation & Fire/explosion & It I /U \\
\hline 221-8: waste drums & $\begin{array}{l}\text { Electrical equipment with } \\
\text { combustibles }\end{array}$ & Fire & $\mathrm{tIt} / \mathrm{A}$ \\
\hline 221-B: cenyon & Conbustible materials & Ignition/fire - explosion & II/A \\
\hline 221-B: operating gallery & Chemical reaction & Caustic/nitric acid mixing & $\llbracket 1 / \mathrm{U}$ \\
\hline 221-B: pipe gallery & Pressure in piping system & Spray leak & $I I I / A$ \\
\hline 271-B: AMS & Chemical reaction & Caustic/nitric acid & III/U \\
\hline 271-B: AN & Pressurized piping & Leak & $111 / \mathrm{U}$ \\
\hline 271-B: ANU & Seismic & Rupture of AMU tank & III/U \\
\hline 211-B: chemical tank farms & Pressurized line & Spray leak during transfer & III/A \\
\hline $\begin{array}{l}\text { 211-BA: chemical sewer } \\
\text { neutral izing facility }\end{array}$ & Tank failure & Pool Spill & $111 / 4$ \\
\hline 212-B: cask station & Kinetic energy & Dropped/ruptured containers & II/U \\
\hline
\end{tabular}


Table 3-3. B Plant Accident Scenarios Requiring Further Examination. (2 sheets)

\begin{tabular}{|c|c|c|c|}
\hline Facility & Hazard & Accident & Severity level \\
\hline 291-B: filters & Seismic event & $\begin{array}{l}\text { HEPA filter housing damage, loss of } \\
\text { canyon ventilation stack or wind } \\
\text { turnel collapse }\end{array}$ & $11 / 0$ \\
\hline 291-B: filters & Retire filters on line & Loss of water seal & $111 / \mathrm{A}$ \\
\hline 291-B: filters & Conbustibles in filter & Fire in filter bank & $111 / u$ \\
\hline 291-B: filters & Explosion & $\begin{array}{l}\text { Hydrogen accumulation as a result } \\
\text { of inadvertent flooding }\end{array}$ & 11/EU \\
\hline 294-B: filters & Moving vehicle & Failed ductwork and filter housing & $111 / 4$ \\
\hline 291-B: filters & Pressure in water lines & Flooding in filter bank & $111 / \mathrm{A}$ \\
\hline 291-B: sand filter & Vehicle impact & Housing col lapse & $111 / \mathrm{N}$ \\
\hline
\end{tabular}

NOTE: Previously B Plant was rated as a moderate hazard facility and tornado events were examined. Under current standards, B Plant is designated as a Safety Significant (Safety Class 2) facility; therefore, high-wind events are analyzed instead of tornados. The 212-B Cask Station is no longer in use and is vacant. The container rupture/drop scenario is no longer applicable.

\author{
AmI = Aqueous makeup unit. \\ $A=$ Anticipated. \\ $\hat{u}=$ Anticipated \\ EU = Extremely \\ I = Incredible.
}


Table 3-4. Seismically Induced Hazards.

\begin{tabular}{|c|c|}
\hline Hazard/effect & Result \\
\hline Loss of conf inement & Canyon walls separate, 271-B collapses, etc. \\
\hline Loss of electrical power & $\begin{array}{l}\text { Loss of ventilation leads to possible buildup of radiolytic } \\
\text { hydrogen. }\end{array}$ \\
\hline Ignition of organics & $\begin{array}{l}\text { Cover block failure will result in tank failure and the presence of } \\
\text { an ignition source to ignite the organic. }\end{array}$ \\
\hline Cover block failure & Tank failure, jumper failure. \\
\hline Red oil explosion & Hot seismically induced (section on red oil). \\
\hline Hydrogen accumulation & 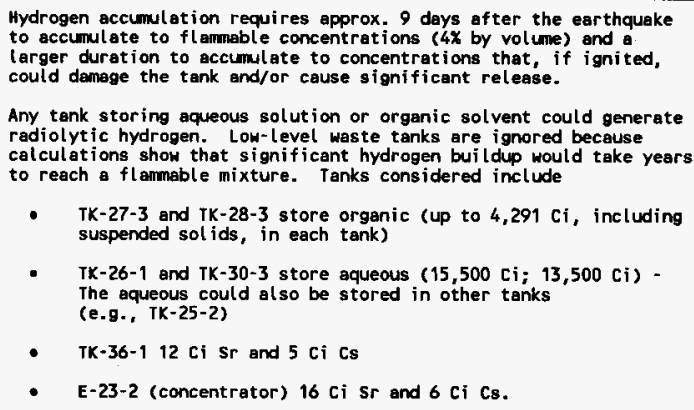 \\
\hline Stean leaks & $\begin{array}{l}\text { Steam leaks do not result in the release of radioactive or toxic } \\
\text { materials and are, therefore, not considered. }\end{array}$ \\
\hline Waste drums & $\begin{array}{l}\text { Material in the waste drums ts assumed to be covered by the } 10^{5} \text { to } \\
10^{6} \mathrm{Ci} \text { of contamination in the cells and on the canyon deck. }\end{array}$ \\
\hline Crane falls & $\begin{array}{l}\text { Crane falls from wall movenent, fails canyon cover block, and falls } \\
\text { into cell. }\end{array}$ \\
\hline $\begin{array}{l}\text { Mixing of caustic and } \\
\text { nitric acid }\end{array}$ & Cons idered. \\
\hline Spray release & $\begin{array}{l}\text { Spray releases of solutions with radioactive materials or toxic } \\
\text { materials in the plant ore considered as part of this analysis even } \\
\text { though it could be ignored based on the short duration of a transfer } \\
\text { and the low probability of transfer coupled with the low probability } \\
\text { of the earthquake. More will be stated in the actual analysis. }\end{array}$ \\
\hline Fire in electrical gallery & $\begin{array}{l}\text { Wot considered because it does not result in a release of } \\
\text { radioactive material. }\end{array}$ \\
\hline $\begin{array}{l}\text { Relese of chemicals in } \\
\text { the tank farm vis a spill }\end{array}$ & Cons idered. \\
\hline $\begin{array}{l}\text { Release of canyon } \\
\text { contamination }\end{array}$ & Considered. \\
\hline HEPA filter housing & $\begin{array}{l}\text { Release because of structure collapse and/or collapse of the stack } \\
\text { onto the structure. High temperature degradation also examined } \\
\text { (organic tank fire section.) }\end{array}$ \\
\hline
\end{tabular}

HEPA = High-efficiency particulate air (filter). 
Table 3-5. Seismic Accident Scenarios.

\begin{tabular}{|l|}
\hline Ignition of organics because of cover block failure \\
\hline Spray releases \\
\hline Hydrogen accumulation \\
\hline Suspension of canyon contanination \\
\hline Mixing of caustic and acid \\
\hline Release of chemicals from the tank farm and AMU \\
\hline Stack failure \\
\hline HEPA collapse or high temperature degradation \\
\hline Filter flooding \\
\hline Tank failure and accumulation in Cell 10 \\
\hline HEPA = high-efficiency particulate air filter.
\end{tabular}

\subsubsection{Accident Analysis}

The accident scenarios warranting further examination are examined in this section. The bounding accidents and the risks associated with these accidents are then identified and the risks are evaluated based on probability (frequency) and consequence. In accordance with WHC-CM-4-46, incredible accidents (i.e., those with frequencies less than $1 \times 10^{-6} \mathrm{yr}$ ) are not evaluated for consequences. Tables 3-6 and 3-7 list the risk acceptance guidelines. Table 3-6 lists the accident frequency and associated radiological risk acceptance guidelines. Table 3-7 provides the toxicological risk acceptance guidelines for accident frequencies.

Table 3-6. Radiological Risk Acceptance Guidelines.

\begin{tabular}{|l|c|c|c|}
\hline \multicolumn{1}{|c|}{$\begin{array}{c}\text { Event frequency } \\
\text { category }\end{array}$} & $\begin{array}{c}\text { Event frequency } \\
\text { range } \\
(y r)\end{array}$ & \multicolumn{2}{c|}{$\begin{array}{c}\text { Effect ive dose } \\
\text { equival ent (rem) }\end{array}$} \\
\cline { 2 - 4 } & $>10^{-2} \leq 10^{-0}$ & Onsite & offsite \\
\hline Anticipated & $>10^{-4} \leq 10^{-2}$ & 25 & 0.5 \\
\hline Unlikely & $>10^{-6} \leq 10^{-4}$ & 100 & 5 \\
\hline Extremely unl ikely & & & 25 \\
\hline
\end{tabular}

Table 3-7. Toxicological Risk Acceptance Guidelines.

\begin{tabular}{|l|c|c|c|}
\hline \multirow{2}{*}{$\begin{array}{c}\text { Event frequency } \\
\text { category }\end{array}$} & Event frequency $(y)^{-1}$ & Primary concentration guidel ines \\
\cline { 2 - 4 } & & Ons & Offsite \\
\hline Anticipated & $>10^{-2}$ to $\leq 10^{0}$ & SERPG-1 & SPEL-THA \\
\hline Unlikely & $>10^{-4}$ to $\leq 10^{-2}$ & SERPG-2 & SERPG-1 \\
\hline $\begin{array}{l}\text { Extremely } \\
\text { unlikely }\end{array}$ & $>10^{-6}$ to $\leq 10^{-4}$ & SERPG-3 & SERPG-2 \\
\hline
\end{tabular}

ERPG = Emergency response planning guidel ines .

PEL = Permissible exposure $l$ imit.

TWA = Time-weighted average. 
Table 3-8 lists the accidents requiring further analysis for potential risk. If an accident is bounded by another accident scenario, the bounding accident scenario is also identified in Table 3-8. The risk associated with the bounding accidents and unbounded accident scenario are then examined. This examination is also part of the Accident Analysis.

The Accident Analysis reexamines previous accident analyses performed for B Plant and also performs new accident analyses.

3.1.3.1 Seismic Analysis. The DBE results in the following potential failures (Section 3.1.2).

- 221-B Canyon - building cracks and gaps; cover blocks fall into cells causing a leak, spill, or fire.

- 291-B Filters - filters A, B, and C and sand filter fail, unless survival with filter degradation from the organic solvent fire yields worse consequences.

- 291-B Stack - stack fails and falls.

The failed structures are designated Safety Significant (Safety Class 2), with the associated $D B E$ of $0.12 \mathrm{~g}$. The $\mathrm{DBE}$ results in an offsite dose rate that is less than the risk acceptance guidelines from WHC-CM-4-46; however, the onsite dose rate exceeds the risk acceptance guidelines. The calculations are found in the Accident Analysis, Section 2.1.1.3.

3.1.3.2 High Winds. Previous analyses of B Plant's vulnerability to high winds determined that most of the facilities will not be affected. Although the analyses showed that some of the uncontaminated support buildings may not stand up to high winds, these buildings do not pose a risk to the public or onsite personnel. The aboveground portions of the 212-B Building may not survive a high-wind event, but the contamination in the 212-B Building is below ground and, therefore, does not pose a significant risk to the public or onsite personnel. The 271-B Building has not been analyzed for high winds. If $271-B$ is assumed to fail, the resulting consequences are below the EPRG-3 limit for onsite exposure and the EPRG-2 limit for offsite exposure. The calculations are provided in Section 2.1.2 of the Accident Analysis.

3.1.3.3 Chemical Tank Farm Spill Release. A spill is postulated to occur during the DBE for sodium hydroxide ( $\mathrm{NaOH}$ ) from the chemical storage tanks. The leak occurs outside on a hot summer day. The release of $\mathrm{NaOH}$ does not violate the criteria for offsite (permissible exposure limit - time weighted average) or onsite (EPRG-1) toxicological dose rate limits (Accident Analysis, Section 2.2). 
Table 3-8. Accidents Identified for Examination.

\begin{tabular}{|c|c|c|c|}
\hline Facility & Hazard & Accident & Bounding accident \\
\hline General facility & Seismic event & Multiple failures & -- \\
\hline General facility & High wind & Multiple failures & $\cdots$ \\
\hline 221-B: organic process cells & Organic vapors & Exposure to vapors/fire & Organic fire \\
\hline 221-B: organic process cells & Seismic event & Tank damage & -- \\
\hline 221-B: organic process cells & Red oil & Explosion & $\cdots$ \\
\hline 221-8: inactive process cells & Hydrogen accumulation & Fire/explosion & $\cdots$ \\
\hline 221-8: waste drums & $\begin{array}{l}\text { Electrical equipment with } \\
\text { combustibles }\end{array}$ & Fire & Organic fire \\
\hline 221-B: canyon & Combustible materials & Ignition/fire - explosion & Organic fire \\
\hline 221-B: operating gallery & Chemical reaction & Caustic/nitric acid mixing & Inadvertent mixing in Am area \\
\hline 221-8: pipe gallery & Pressure in piping system & Spray leak & Chemical tank farm spray leak \\
\hline 271-8: AnU & Chemical reaction & Caustic/nitric & -- \\
\hline 271-B: Am & Pressurized piping & Leak & Inadvertent mixing of chemicals \\
\hline 271-B: ANU & Seismic & Rupture of MAU tank & -- \\
\hline 211-8: chemical tank farms & Tank Failure & Spill & -- \\
\hline $\begin{array}{l}\text { 211-8A: chemical sewer } \\
\text { neutral izing facility }\end{array}$ & Pressurized line & Spray leak & Rupture of chemical storage tank \\
\hline 221-B: Tank TK-10-1 & Red oil & Explosion containers & -- \\
\hline 291-8: filters & Seismic event & $\begin{array}{l}\text { HEPA filter housing damage, loss of } \\
\text { canyon ventilation stack or wind } \\
\text { tumel collapse }\end{array}$ & -- \\
\hline 291-B: filters & Retire filters on line & Loss of water seal & Organic fire \\
\hline 291-B: filters & Combustibles in $f i l$ ter & Fire in filter bank & -- \\
\hline 291-B: filters & $\begin{array}{l}\text { Hydrogen accumulation as a result } \\
\text { of inadvertent flooding }\end{array}$ & Explosion & Organic fire \\
\hline 291-B: filters & Moving vehicle & Failed ductwork and filter housing & Organic fire \\
\hline 291-B: filters & Pressure in water lines & Flooding in filter bank & Organic fire \\
\hline 291-B: sand filter & Vehicle impact & Housing coll lapse & Organic fire \\
\hline
\end{tabular}

ANU = Aqueous makeup unit

HEPA = High-efficiency particulate air. 
3.1.3.4 Inadvertent Mixing of Chemicals in 271-B AMU. This accident scenario postulates the spill of $\mathrm{NaOH}$ and nitric acid $\left(\mathrm{HNO}_{3}\right)$ in the 271-B AMU area.

The release of chemicals does not violate the criteria for offsite toxicological dose rate limits or the onsite toxicological dose rate limits for high probability events. The calculations are performed in Section 2.2.2.4 of the Accident Analysis.

3.1.3.5 Red 0il Explosion. Red oil is a very heavy substance that forms during a rapid chemical reaction when $\mathrm{HNO}_{3}$ is added to an organic solution containing tributyl phosphate and the mixture becomes heated. This reaction generates offgas because of the degradation of nitrated compound. The red oil reaction and subsequent gas generation in a confined environment yields an explosion. Section 2.3.2 of the Accident Analysis concludes that the possibility of a red oil event at B Plant is incredible. The system is now configured so that the interconnecting piping between the $\mathrm{HNO}_{3}$ tanks and the organic tanks has been removed. Therefore, no credible way to introduce $\mathrm{HNO}_{3}$ into the organic tanks exists.

Mixing of $\mathrm{HNO}_{3}$ and organic solution could occur in tank TK-10-1, which is the cell drain header tank. This is a large, rectangular tank that is open at the top. Explosive reactions involving degraded organic can only occur in closed systems. Open systems (tanks) allow for the rapid venting of reaction products. Because superheating cannot occur, pressurization of the tank is not possible. The contents of the tank may froth and boil over, but an event which would result in a release to the environment is deemed incredible.

3.1.3.6 High-Efficiency Particulate Air Filter Fire. Burning embers cannot reach the HEPA filters because cool air from other parts of the 221-B Canyon mix with the air from the filter fire. The air tunnel is also long, making the possibility of a hot ember reaching the HEPA filters extremely unlikely. However, the accident analysis is performed (Accident Analysis, Section 2.3.3.2) and the results are within the risk acceptance guidelines.

3.1.3.7 Organic Solvent Fire. This organic solvent fire scenario assumes that a cover block falls and destroys the tank(s) containing the organic solvent, and thereby plugs the cell drain header and traps the solvent in the cell. The falling cover block creates an ignition source and the organic solvent burns. The smoke from the fire exhausts through the ventilation system and out the stack. The calculations for this scenario are developed in Section 2.3.3.1 of the Accident Analysis and show consequences well below the guidelines.

3.1.3.8 Radiolytic Hydrogen Generation. Radiolytic hydrogen generation is examined in the Accident Analysis for a tank containing organic solvent and a tank containing aqueous solution. All aqueous solution is combined in another location, and all organic solvent is combined in one location. The aqueous solution generates hydrogen at a slightly higher rate than the organic solvent. The calculations in Section 2.3.1 of the Accident Analysis show a radioactive material release resulting from hydrogen explosion in the cells does not exceed the risk acceptance guidelines. 
If a power failure occurs and the power is not restored, hydrogen accumulates in the process cells. The generation of hydrogen could become a problem in approximately 9 days. Section 2.5 of the Accident Analysis shows a hydrogen explosion from the loss of power event is within guidelines.

3.1.3.9 Design-Basis Ashfall/Snow Load. The DBA has a frequency of $2.08 \times 10^{-3}$ per year. The consequences for a DBA for the 221-B Canyon do not exceed the onsite and offsite risk acceptance guidelines per WHC-CM-4-46.

3.1.3.10 0ther Analyses. Besides the hazards and accident scenarios identified in the PHA, other scenarios are examined in the Accident Analysis. A release of radioactive material via an organic solvent spray leak is included. The spray leak does not violate the onsite or offsite dose limit criteria (Accident Analysis, Section 2.2.1). The flood scenario is examined and determined to not pose a hazard for B Plant (Accident Analysis, Section 2.1.3).

\subsection{HAZARDS CONTROLS} controls.

The Accident Analysis determines the following B Plant interim hazard

- There are no interim operational safety requirements (IOSR) for B Plant interim activities based on the conclusions found in the Accident Analysis. WHC's technical safety requirements (TSR) policy is contained in WHC-CM-4-46, Chapter 6.0, "Technical Safety Requirements." IOSR are identical in intent and content to TSR, but differ because they are based on an ISB rather than a final safety analysis report that meets the requirements of DOE Order 5480.23.

- Only an aqueous spray leak results in unmitigated offsite doses greater than 0.5 rem or unmitigated onsite doses greater than 5 rem (excluding the natural phenomena events of DBE); therefore, there are no safety limits, limiting control settings, or limiting conditions for operation. However, the stack for non-DBE is designated as Safety Significant (Safety Class 2) to mitigate this event. Section 3.2.1.2 provides further details.

- There are no surveillance requirements because there are no limiting conditions for operation.

- Design features employed to withstand natural phenomena events, ensure worker safety, and ensure radiological protection are discussed in the WHC-SD-WM-PHA-008, Rev. 0, WHC-SD-WM-TM-004, Rev. 2, and the Accident Analysis. The unreviewed safety question (USQ) process, discussed in Section 4.4, ensures that changes made to design features are controlled so that they do not adversely affect facility safety.

None of the current B Plant operational processes have the potential to increase the facility radiological or chemical inventories. The inventories continue to decrease as cleanout and stabilization activities progress toward 
long-term surveillance and maintenance and, ultimately, D\&D. The USQ process (Section 4.4) ensures that the B Plant inventory remains at or below the level assumed in the Accident Analysis.

\subsubsection{Safety Class Structures, Systems, and Components}

The Safety Class (Safety Class 1) and Safety Significant (Safety Class 2) structures, systems, and components are discussed in the following subsections. As WHC has now adopted the Safety Class and Safety Significant designation for safety classification, the use of Safety Class and Safety Significant are used interchangeably with Safety $\mathrm{Cl}$ ass 1 and Safety Class 2, respectively. All previous B Plant safety analyses used the older safety classification designation.

3.2.1.1 Structures. The original B Plant design was based on the requirements of the Uniform Building Code (UBC 1940), which required resistance to a lateral force resulting from a dead load on the structure, but did not require resistance to lateral acceleration forces resulting from an earthquake. Standard Architectural-Civil Design Criteria Design Loads for Facilities, Rev. 11 (SDC-4.1); DOE Order 6430.1A, General Design Criteria; and Design and Evaluation Guidelines for Department of Energy Facilities Subjected to Natura7 Phenomena Hazards, UCRL-15910 (LLNL 1980), contain the current seismic criteria for the design of nonreactor facilities at the Hanford Site. Based on the safety classification of the B Plant facilities, the contents of the facilities are conservatively assumed to escape to the environment without mitigation during a DBE. Table 3-9 provides the seismic qualification for the facility safety classifications. The safety classification also serves as the basis for determination of seismic adequacy/qualification of the facilities and structures. As determined in the following sections, some facilities are not seismically qualified for their safety class DBE.

Table 3-9. Seismic Qualification Facility Safety Classifications.

\begin{tabular}{|l|c|}
\hline \multicolumn{1}{|c|}{ Facility } & Safety Class \\
\hline 221-B Canyon Building & SS (SC-2) \\
\hline $291-$ B Duct and stack & SS (SC-2) \\
\hline 291-B Filter Structure & USC (SC-3) \\
\hline 211-B Chemical Storage Tanks & NSC (SC-3) \\
\hline 212-B Cask Loading Station* & NSC (SC-3) \\
\hline 271-B AMU Tanks & NSC (SC-3) \\
\hline
\end{tabular}

"Building 212-B is inactive. However, residual contanination remains.

SS $=$ Safety significant

NSC $=$ non safety class

SC-2 = Safety Class 2

SC-3 = Safety Class 3 
As a minimum, UCRL-15910 specifies that an elastic dynamic analysis should be performed for Safety $\mathrm{Cl}$ ass 1 and 2 structures and resulting demand/capacity ratios should be calculated for the structure. If the demand/capacity ratios are below unity for the entire structure, the facility is considered seismically adequate. If the demand/capacity ratios are not below unity for the entire structure, inelastic analysis is necessary to allow redistribution of the local peak demands. Evaluations of Safety $\mathrm{Cl}$ ass 3 facilities are based on normal building code seismic provisions. UCRL-15910 also addresses special considerations for existing facilities and emphasizes the need for establishing the as-built condition of the facility and materials of construction. The specified probability of exceedance for maximum ground accelerations noted in UCRL-15910 are as follows:

$$
\begin{aligned}
& \text { - } 2 \times 10^{-4} / \mathrm{yr} \text { for Safety Class } 1 \\
& \text { - } 1 \times 10^{-3} / \mathrm{yr} \text { for Safety Class } 2 \\
& 2 \times 10^{-3} / \mathrm{yr} \text { for Safety Class } 3 .
\end{aligned}
$$

The UCRL-15910 probabilities correspond to current requirements for maximum horizontal ground surface accelerations of $0.2 \mathrm{~g}, 0.12 \mathrm{~g}$, and $0.09 \mathrm{~g}$. Most of the analyses reviewed were performed when B Plant was considered a Safety Class 1 facility. Maximum ground surface accelerations of $0.2 \mathrm{~g}$ and $0.25 \mathrm{~g}$ were used in these analyses, depending on when the analyses were performed. Limiting analyses were also performed for a 0.19 Hanford Regional Historical Earthquake (HRHE). Many of the structures that are overstressed in the original calculations may prove adequate in view of the reduced seismic demands for a Safety Class 2 facility. Because of the nonlinear nature of many of the analyses, linear scaling of all model results is not possible; however, the calculated stresses that are much larger than the material allowable cannot be justified without further analysis. No such analysis was performed during the publication of this document.

The confinement boundary of B Plant is comprised of the 221-B walls, floor, and roof, and is maintained by the ventilation system. All analyses of the components that define the confinement boundary must meet the criteria discussed previousiy. The previous analyses conservatively predicted the structure displacements and stresses and, therefore, envelop current $D O E$ requirements.

\subsection{Previous Analyses of 221-B: B Plant Canyon Structure.}

The first analysis to seismically qualify the canyon structure to current standards was performed using linear elastic dynamic analysis techniques and is referred from B Plant Structural Qualification Interim Report, WHC-SD-WM-SA-001, Rev. O (WHC 1991a). This analysis examined the feasibility of demonstrating compliance of the 221-B Canyon structure with DOE requirements for a Safety Class 1 facility. The first step was a detailed, nondestructive inspection of the structural elements of the reinforced concrete facility. A linear elastic dynamic finite element analysis that includes the concrete tension capabilities was conducted for a $0.2 \mathrm{~g}$ DBE. Soil-structure interaction effects were included, but inelastic effects were not. The analysis methodology meets current (i.e., 1995) guidelines for a Safety Class 1 facility, but several areas of high stress were identified. 
The report concluded that to structurally qualify the 221-B structure, a more detailed nonlinear evaluation was required. A nonlinear static analysis was also proposed to identify the potential collapse mechanism and the static load capacity.

An analysis with the recommended nonlinearities was conducted in the $B$ Plant Canyon Structure Seismic Evaluation, WHC-SD-WM-SA-005, Rev. 0 (WHC 1991b). The analysis planned to first determine the as-built condition and the current condition using standard nondestructive testing techniques. Considerable effort was spent in developing a model that accurately characterizes the nonlinear behavior of the various construction joints. Both static and dynamic analyses were then conducted. The static analyses predicted a positive margin against collapse for the DBE of $0.2 \mathrm{~g}$ with a collapse load of $\approx 0.4 \mathrm{~g}$.

The nondestructive examination showed that the concrete in the north and south canyon walls was in good-to-excellent condition, with minimal degradation and cracking. The cracks that existed were 15- to 23-cm deep at a maximum. Some of the construction joints were unbonded. Similar findings were made for the roof and galleries.

An elastic analysis was next performed using response spectrum techniques. The initial elastic analysis indicated that there were several locations of local overstress. As a result, it was decided to follow up with an inelastic analysis in order to secure a comprehensive understanding of the potential structural responses during the postulated seismic event.

The inelastic analysis was performed using a nonlinear finite element mode1. The inelastic dynamic analysis predicted peak plastic strains of less than $2 \%$ for the reinforcing bar. The ultimate strain for Grade 40 reinforcing bar is $12 \%$, which indicated a significant margin against failure. Gapping at the construction joints and cracking of the concrete were not precluded; although, no complete through-thickness cracking was predicted. Demand/ capacity curves generated for the canyon roof and walls verified compliance with the capacities defined in UCRL-15910.

The results of the inelastic analysis were used to perform a nonlinear time-history analysis. The inelastic time-history analyses results indicated that rebar yielding occurs at the crane level. The outer rebar at the north crane wall showed the largest strains. The analysis showed a peak plastic strain of $1.6 \%$ against an ultimate strain of $12 \%$. The structure was deemed stable if the north deflections stayed below $1.91 \mathrm{~cm}$ and south deflections stayed below $3.18 \mathrm{~cm}$. The analys is showed displacements of 0.56 and $1.22 \mathrm{~cm}$, which indicated that the section strength was not exceeded at any location. This analysis showed seismic adequacy relative to UCRL-15910. Further analyses showed that accelerations of about $0.4 \mathrm{~g}$ are necessary for collapse of the building. While the building will not collapse, gapping and yielding at construction joints is expected.

B Plant Canyon Structure Seismic Evaluation Review Documentation, WHC-SD-WM-SA-007, Rev. O (WHC 1990a), concluded that the structural analysis of the canyon performed by WHC was thorough and fully complied with all applicable criteria contained in DOE 6430.1A, UCRL-15910, and SDC-4.1 for the specified DBE of $0.2 \mathrm{~g}$. Recommendations from the independent review were 
noted. The previously described analyses were performed with a two-dimensional plane model of the canyon cross section, so that the end-walls were not modeled. The study recommended that the effect of these end-walls be evaluated. Also, the 271-B Support Building adjoins the canyon north wall, and the interaction of these two structures should be evaluated.

B Plant Canyon End-Wall Study, WHC-SD-WM-SA-013, Rev. 0 (WHC 1995a), determined the effect of the canyon end-walls. The analysis evaluated the end-wall structural integrity and stability and the interaction of the end-wall with the adjacent segment of canyon structure. In the analysis, both linear static and dynamic analysis techniques for a DBE of $0.2 \mathrm{~g}$ were used. The shear keys between the end-wall and the canyon structure were found to be overstressed; however, a rocking analysis of the end-wall without considering shear keys showed that the walls were stable. The end-wall analysis predicted stresses in the shear keys that are excessively high. The analysis results did not indicate collapse of the canyon structure; however, the analytical methodology used did not demonstrate compliance with DOE requirements for a Safety Class I facility. While a Safety Class 2 earthquake is lesser in magnitude, Safety Class 2 seismic qualification cannot be concluded from this analysis either.

The two buildings adjacent to the 221-B Canyon structure present potential hazards because of seismic displacements. The B Plant Building Interface Study, WHC-SD-WM-SA-014, Rev. O (WHC 1991c), evaluated the interaction of the 225-B and 271-B Buildings with the canyon. Earthquake Analysis of the Waste Encapsulation Facility, JABE-VITRO-01 (Blume 1971), concluded that the 225-B facility was designed to withstand a $0.25 \mathrm{~g}$ seismic event. Also, a $5.1-\mathrm{cm}$ seismic gap isolates the 225-Building from the canyon structure. An evaluation of the calculated displacements proved that no interaction occurs between the 225-B Building and the canyon structure; therefore, no analysis is necessary.

The 271-B Facility adjoins, but is not structurally anchored to the canyon facility. The evaluation of the 221-B/271-B interaction used previous analyses (WHC 1990a) of the 221-B Facility to impose acceleration loads on a combined 221-B/271-B model developed for this study. A true dynamic interaction analysis was not performed, but the study concluded that the 271-B Building would not impose sufficient additional loadings on the canyon to result in failure.

Another area of concern for the 221-B Facility is the relative displacement of the horizontal construction joints on the north and south walls and the vertical expansion joints between 12.2-m segments. During a seismic event, confinement boundary leakage from through-wall cracking or gapping of these joints was postulated. Results from the original analysis (WHC 1990a) of the 22l-B Facility were used to evaluate the construction joint. An analysis of these results showed that the horizontal construction joint displacement and rotations were small and would not result in a through-wall leak path. The vertical expansion joints were evaluated separately by using a soil-structure-interaction model to conservatively predict the gapping. The maximum displacements were determined to be insufficient to produce gapping in the expansion joints, as a result of the 
$0.2 \mathrm{gBE}$. The reference contains further hand calculations to determine the impact forces generated between $12.2-\mathrm{m}$ segments during a seismic event. The calculated stresses were found to be within allowable code limits.

The $B$ Plant Confinement Study, WHC-SD-WM-SA-012, Rev. 0 (WHC 1991d), defines the canyon confinement boundary to determine whether the existing structures and components will maintain confinement under seismic loading. Previous analyses and evaluations of components not addressed in other analyses were summarized in that document. Various access doors in the canyon were evaluated for the $0.2 \mathrm{~g}$ seismic event by using hand calculations and detailed numerical models. The resulting stresses and displacements were low and thereby verified the structural integrity of the access doors during the specified seismic event. The results indicated the following.

- The west wall contains two openings that allow access from 221-B to WESF. The floor frame is distributed less than $0.25 \mathrm{~cm}$ and, therefore, survives the earthquake.

- The west wall will not collapse, but gaps will form between the walls and the rest of the structure.

- The 221-B Building and WESF will not impact each other.

- The 10 canyon doors on the south side are not failed or opened by seismic forces. The peak displacement is $0.08 \mathrm{~cm}$.

- The air tunnel will remain intact, but will have some cracking.

- The stair wells on the north side could collapse but the doors will remain closed.

It is assumed the wall movement will cause the crane to fall from the movement of the rail and impact the coverblocks causing some cracking and minor structural damage, and the jumpers will leak but the coverblocks will remain intact during the event to prevent spray to the canyon and out the facility through the gaps.

221-B Cover blocks. The structural analys is referred to above demonstrated that the stresses and displacements for the structure at or near the vicinity of the canyon deck were minor. This was determined because the structure is quite massive and well tied together in this location and because the horizontal and vertical accelerations were almost identical to those of the ground (no amplification or differential accelerations). The process cell cover blocks are a concern because of their size and the presence of organic solvent and aqueous solution. These cover blocks are 1.8-m thick and have a stepped construction. There are four cover blocks per cell, with a cell dimension of 5-m long and 4-m wide. The weight is about $57,700 \mathrm{~kg}$ for each cover block. As a result, the natural frequency of the cover block is similar to the structure around it and, therefore, the cover block should not fail. The stepped construction also protects against the cover block falling into the cell because the weight rests on many edges rather than on two edges, as in the case of single-ear cover blocks used at WESF. It might therefore be possible to qualify the cover blocks against failure. Because this qualification is not yet done, it is assumed, as in the safety analysis report 
(WHC-SD-WM-SAR-013, Rev. 2 [WHC 1993a]), that the cover blocks can fall into the cells.

Equipment. The equipment in the process cells is supported by a variety of bases, depending on the length of the tank. At the top, the tanks and other equipment are connected to the sides of the process cell via jumpers. The jumpers are made of heavy pipe. Seismic effects could cause the partial breaking of a jumper connection and equipment could fall over onto the side of the cell (the equipment being typically too large to fall completely over in the process cells). Fracturing of the top of the vessel or sides near the top of the vessel could occur, if any of these vessel walls are weak as compared to the jumpers that rigidiy hold the top nozzles. However, the fracturing of the vessel is extremely unlikely because the vessels walls, top, and bottom are typically made of $1.27-\mathrm{cm}$ thick stainless steel. If the cover block falls into the cell, vessel fracturing could occur. The extent of the fracturing is dependent on the number of jumpers that are present and act to break the fall of the cover block, the size of the cover block pieces, and distance of the fall. As a result, the assumed damage includes the following.

- If a cover block remains in place, the damage is jumper leaks or openings in the jumper/tank connection.

- If a cover block falls, the damage is small openings in the top or bottom of the tank.

Cell Drain Header. The B Plant Cell Drain Header Seismic Analysis, WHC-SD-W024H-SA-001, Rev. O (WHC 1991e), was referred to for this study. In this study, it is evaluated for a $0.12 \mathrm{~g}$ lateral acceleration and is assumed to survive a Safety Class 2 seismic event.

Conclusion for 221-B. The conclusions for the 221-B Facility seismic analysis include the following.

- 221-B structure will not collapse.

- There are gaps in the construction joints and in the meeting of the east and west walls with the north and south walls.

- The crane will fall from movement of the rail.

- Cover blocks are assumed to fall into the cells.

- Jumper loss or massive tank breach can occur in the organic process cells because of cover blocks.

\subsection{Previous Seismic Analyses of Canyon Exhaust Ventilation}

System. B Plant Support Facilities Natural Forces Evaluation, WHC-SD-WM-TA-002, Rev. O (WHC 1983), analyzed the filter cells for seismic loads. The maximum seismic demands were determined for the walls of the cell by using a safe shutdown earthquake (SSE). The SSE is an earthquake with a zero period acceleration of $0.25 \mathrm{~g}$ with an applicable ground response spectrum. Soil loads were also determined. 
The $A$ and $B$ filter cells analysis found that the roof and the roof supports survive the SSE, but the north wall fails because of the soil pressures generated by seismic motion. The results also predicted cracking with possible resultant loss of the water seal. The north wall failure could also result in the collapse of the entire cell. If the cell remains intact, the HEPA filter frames would survive the SSE motions.

The roof and support columns of the $C$ filter cell will survive the SSE. The south wall panels between the pilasters will fail because of soil pressures generated by seismic motions. The pilasters are marginal. Failure of the south wall could cause the loss of the water seal and potentially result in the collapse of the cell. If the cell survives, the filter support frames will survive the SSE intact.

The structure of the D filter cell will survive the SSE loads and motions. The steel in the prefilter will yield, causing the prefilters to leak. The HEPA filters could experience impact loads because of the loosening of the anchor bolt for the center support strut. The strut might also fall away, depriving the frame of its center support. The analysis results also show that if the differential pressure is above $5.8-\mathrm{cm}$ of water, the anchor bolt will not pull out.

WHC 1983 also provided an assessment of the A-D filter cells under the $0.12 \mathrm{~g}$ earthquake. The information in the document is not presented clearly; however, it appears that the failures discussed for the $0.2 \mathrm{~g}$ earthquake will al so occur, as a result of the $0.12 \mathrm{~g}$ earthquake.

It is assumed from WHC 1983 that the A, B, and C filter cells collapse. The $D$ filter cell will remain intact.

The B Plant Canyon Exhaust Ductwork and Filter Study, WHC-SD-WM-SA-016, Rev. 0 (WHC 1991f), assessed the ability of the canyon exhaust duct and filter system to withstand seismic and other loadings. The study summarized several different analyses performed over the last 15 years. The seismic events used for these analyses $(0.20$ and $0.25 \mathrm{~g})$ resulted in conservative loadings.

Limited analyses were completed for a $0.10 \mathrm{~g}$ HRHE. The stated goal of the study was to collect and evaluate the existing analyses, recommend additional work, and lay the groundwork for future work by providing a concise system description and reference lists. Many of the analyses summarized are taken from an earlier report (WHC 1983). Unfortunately, many of the calculational details of these analyses are not available. The study reached the following conclusions.

- The underground ducts may sustain local cracking but catastrophic failure is unlikely.

- Filter cells $A, B$, and C will experience partial failure.

- Local cracking could also cause the water seals of out-of-service filters to fail.

- Filter cell D design is acceptable but the HEPA filter bank is suspect. 
- Filter cell E design analyses are inadequate.

- Filter cell $\mathrm{F}$ design calculations are adequate.

- The sand filter is not adequate for seismic event.

- The exhaust stack is susceptible to seismic events.

After reviewing the study, the following recommendations are made.

- Further analysis of A, B, and C filters may be required.

- E filter should be reanalyzed to current standards.

- The sand filter should be reanalyzed, if the filter is critical to operations and cannot be replaced.

- The exhaust stack is vulnerable to earthquake loadings and additional analysis may be necessary.

An overall conclusion for the exhaust system is not possible on the basis of the information evaluated. Instead, specific conclusions concerning each component can be made. The exhaust duct analysis was thorough and conservative and, therefore, the exhaust duct analys is is considered adequate. Filters $A, B$, and $C$ are marginal for the $0.2 \mathrm{~g}$ DBE. A conclusion cannot be drawn for a $0.12 \mathrm{~g}$ DBE without a detailed evaluation. Analysis of the $D$ filter cell predicts the reinforced concrete structure will survive the $0.25 \mathrm{~g}$ earthquake, but yielding will occur in the filter frame. This filter uses the same filter support frames as E filter, which is shown in subsequent detailed analysis to be adequate and, therefore, $D$ and $E$ filters are considered to survive the $0.12 \mathrm{~g} \mathrm{DBE}$. B Plant Filter Design Calculations (ICF KEH 1991) evaluated $F$ filter to the requirements of SDC-4.1, Rev. 10. The details of these calculations are not available, but the requirements of Rev. 10 are generally more severe than those of Rev. 11 and $F$ filter is thus considered adequate for the $0.12 \mathrm{~g} \mathrm{DBE}$. The sand filter cannot adequately resist the $0.10 \mathrm{~g}$ HRHE and would probably collapse.

A subsequent analysis of $E$ filter was conducted in the $B$ Plant Seismic Qualification of E Filter, WHC-SD-W239-SA-001, Rev. O (WHC 1993C). It should be noted that both $E$ and $F$ filters have never been contaminated and $B$ Plant does not intend to use $F$ filter. In the analysis, linear elastic static analysis was used to qualify $E$ filter. An argument was made concerning the use of a static analysis versus the UCRL-15910 for dynamic analysis. It was noted that evaluation of the $F$ filter used dynamic analysis techniques with no significant change in the response. Because of the close proximity of the $E$ and $F$ filters and the similarity in configuration, a dynamic analysis of the E filter is not deemed necessary. Results from the analysis predicted local overstressing for the DBE of $0.2 \mathrm{~g}$. Also, cracking was calculated to occur, but the structural integrity and function of the filter were not expected to be compromised. Linear scaling of the calculated stresses showed that the structure would not be overstressed for the $\mathrm{DBE}$ of $0.12 \mathrm{~g}$. As a result of the reduced seismic demand, the $E$ filter housing and frame were considered structurally adequate. 
Conclusions for the Canyon Exhaust Ventilation System. Filter cells A, $B$, and $C$ are assumed to experience some failure. New analyses could demonstrate survival. The sand filter is seismically inadequate. A new analysis might or might not demonstrate seismic qualification.

3.2.1.1.3 291-B Stack. WHC 1983, analyzed the B Plant stack. This document concluded that the vertical steel reinforcement would yield and that the stack foundation is unstable (overturning possible) at $0.12 \mathrm{~g}$. At $0.25 \mathrm{~g}$, the concrete stresses exceed allowable limits. WHC 1983 also showed that the masonry is incapable of resisting lateral motions and would fail.

$A R$ Vault, AR Stack, and B Plant Stack Seismic Evaluation, internal letter, SA:GRW 89-15 (Conrad and Wagenblast 1989), provided a prel iminary assessment of the B Plant stack. The analysis was performed to the requirements of DOE Order $6430.1 \mathrm{~A}$ and UCRL-15910. The evaluations used static methods and dynamic analyses were to follow later. Engineering experience shows that dynamic analyses usually increase the margin to failure.

The stack was analyzed as a cantilevered beam held at the base. A peak acceleration of $0.33 \mathrm{~g}$ was applied to the entire mass of the stack, assuming it was all at the stack's center of mass. The value of $0.33 \mathrm{~g}$ was obtained by using the peak acceleration from a $10 \%$ damped response spectrum curve anchored at $0.2 \mathrm{~g}$. The results of this analysis indicated that the stack was unstable and would collapse (topple over) with this load. The analysis also showed that the load would have to be reduced by $50 \%$ to demonstrate survival. A preliminary response spectrum evaluation was also performed. This analysis showed that the use of $0.33 \mathrm{~g}$ over the entire mass was very conservative. This analysis also showed that only $25 \%$ of the mass experiences $0.33 \mathrm{~g}$ and the rest experience lessor $\mathrm{g}$ values. This response spectrum analysis demonstrated that the use of dynamic analysis would most likely demonstrate survival; however, the dynamic analysis has not yet been performed.

Based on WHC 1983, the internal brick of the stack is assumed to fall into a large pile within the stack. The stack itself is also assumed to fall at both $0.12 \mathrm{~g}$ and $0.25 \mathrm{~g}$ earthquakes; however, based on the response spectra analysis, the entire stack is not assumed to fall (i.e., the damage radius is $<61 \mathrm{~m})$.

The evaluation of the stack in Conrads and Wagenblast's internal letter determined the stack could survive the $0.12 \mathrm{~g}$ earthquake. However, WHC 1983 states that the stack is unstable with regards to overturning motions and the stack is assumed to fall.

The 291-8 stack was evaluated for both the HRHE of $0.1 \mathrm{~g}$ and the SSE of $0.25 \mathrm{~g}$ (WHC 1991f). The results predicted that the stack would likely collapse during the SSE event, but the stack was considered adequate to resist the $0.10 \mathrm{~g}$ event with some loss of function because of the masonry liner collapsing. The study is inconclusive with regards to the $0.12 \mathrm{~g} \mathrm{DBE}$.

3.2.1.1.4 Previous Seismic Analyses of 211-B: Chemical Storage Area. WHC 1983 evaluated other components that are not critical for B Plant confinement, including 211-B. The Chemical Storage Areas were classified as Safety Class 3 structures. The 211-B Chemical Storage Area consists of a 
series of horizontal and vertical aboveground tanks, associated piping, and access and support platforms.

The equivalent static method was used in WHC 1983 for these tanks. The seismic analysis was based on $0.2 \mathrm{~g}$. The 1 iquids in the tank, as well as the tank, were assumed to be subjected to the peak horizontal response spectra accelerations. The internal pressure caused by the acceleration of the liquid and the forces on the concrete haunch and footing, which support the tanks, were determined and the stresses were combined using existing industry practice.

The results for the horizontal tanks concluded that the dead weight by itself creates excessive soil-bearing pressures with unacceptable factors of safety. These pressures result in movements that would overturn the tank, break the supports and subsequently collapse the tank.

The vertical tank is $3-\mathrm{m}$ in diameter by $4.3-\mathrm{m}$ high. The analysis of the vertical tanks indicated that the horizontal loading will buckle the vertical supports and overload the foundation anchors. The result is that these tanks will also fail. The analysis also showed that the tank piping will fail.

Conclusions for 211-B. Several upgrades have been made to the 211-B Chemical Storage Area subsequent to this analysis and are documented in Preliminary Safety Analysis Report, B Plant Environmental Compliance Upgrades 211-B Chemical Tank Farm and 211-B Gallery Scale Tanks, WHC-SD-WO10H-PSAR-001, Rev. $O$ (WHC 1993d). A retention bas in to provide secondary containment for each group of tanks has been added. These reinforced concrete basins were designed per Safety Class 2 seismic criteria. The tank supports, piping, piping supports, and associated equipment have been modified to meet seismic criteria for Safety Class 3 structures; however, the vertical supports were removed, and $\mathrm{HNO}_{3}$ is not presently stored at 211-B. In light of the reduced seismic resistance requirement and increased structural capacity, the chemical storage area is adequate as a Safety Class 3 structure.

3.2.1.1.5 Previous Seismic Analysis of 212-B: Cask Loading Station. The 212-B Building is inactive and the casks have been removed, but residual contamination remains and thus it is examined.

WHC 1983 analyzed the Cask Loading Station for both $0.1 \mathrm{~g}$ and $0.25 \mathrm{~g}$ seismic event. The 212-B Cask Loading Station, which is classified as a Safety Class 3 structure, consists of three separate structural components:

- Below grade operating gallery constructed of reinforced concrete

- Above grade operating gallery constructed of a structural steel frame with siding

- Above grade enclosure additions.

These above grade and below grade areas were evaluated separately. The stresses for the below grade gallery during the seismic events were within code limitations. A response spectrum analysis of the above grade portions of the Cask Loading Station indicated that the structure was adequate for both seismic events considered. The east-west (two dimensional) structural support 
member at column line 2 of the cask-handling area was analyzed for earthquake motions. The results of the analysis were that the cask-handling area can survive a $0.2 \mathrm{~g}$ seismic event with the stresses remaining within code allowables. The structure was assumed to remain intact with the contamination contained; therefore, the main structural components of the 212-B Cask Loading Station are adequate to resist the $0.09 \mathrm{~g}$ seismic event required for a Safety class 3 structure.

Only a qualitative appraisal was made for the enclosures on the north and south sides. These enclosures are not part of the main portion of the building (the cask-handling area). The enclosures have no movement-resistant connections; therefore, the siding provides only minimal lateral force resistance. These enclosures were considered inadequate for the seismic events considered; however, the contamination levels of the north and south enclosures are very small, meaning that collapse will result in little or no release.

3.2.1.1.6 Seismic Analyses of Other B Plant Support Facilities. The B Plant Complex is composed of a number of small buildings (e.g., compressor buildings, pump houses) that are not contaminated and may contain extremely small quantities of hazardous materials. Complete collapse of the buildings during a seismic event would not yield consequences above the risk acceptance guidelines.

3.2.1.2 Seismic Analysis Conclusions. Several deficiencies, with respect to current DOE requirements, are noted from the previous analyses. The canyon end-wall evaluation predicts excessively high stresses in the shear keys, but the wall is predicted to remain stable after shear-key failure. The analysis provides adequate assurance that the end-walls are structurally stable, but a time-history dynamic analysis would be required to establish that the walls can be classified as a Safety Class 1 structure. The end-wall analyses are also considered inadequate to confirm the structural stability of the end walls to Safety Class 2 criteria $(0.12 \mathrm{~g})$. The organic process cell cover blocks are also assumed to be seismically unqualified.

The sand filter is found to be inadequate for the HRHE of $0.1 \mathrm{~g}$, which indicates that the structure would not survive the $0.12 \mathrm{~g} \mathrm{DBE}$. On the basis of the analyses reviewed, filter cells $A$ through $C$ would be expected to fail the $0.12 \mathrm{~g} \mathrm{DBE}$. Similarly, the 291-B stack is structurally inadequate for the DBE. The assumed failures are listed in Table 3-10. 
Table 3-10. Summary of Assumed Failures for $0.12 \mathrm{~g}$ Design-Bas is Earthquake.

\begin{tabular}{|l|l|}
\hline \multicolumn{2}{|c|}{$221-8$ Canyon } \\
\hline Structure & $\begin{array}{l}\text { Structure renains intact. There are gaps in the construction joint } \\
\text { and in the area where the east and west wall meet the north and } \\
\text { south walls. The crane falls to the floor of the canyon. }\end{array}$ \\
\hline Crane & Falls, fails cover block, and falls into cell. \\
\hline Cover blocks & $\begin{array}{l}\text { Falls, ruptures tank or breaks jumper connection, snd starts fire } \\
\text { or spray leak. }\end{array}$ \\
\hline A and B filters/vaults & \multicolumn{1}{|c|}{$291-B$ Filters } \\
\hline C filter/vault & North wall fails with a potential collapse. \\
\hline water seals & South wall fail with potential collapse. \\
\hline Stack & Could leak as a result of cracking. \\
\hline
\end{tabular}

3.2.1.3 System and Components. Unmitigated nonseismic events do not exceed onsite or offsite guidelines for dose or exposure except for an aqueous spray release. There are no Safety Class (Safety Class 1) systems or components identified to prevent or mitigate credible accident scenarios that result in unmitigated offsite doses greater than $0.5 \mathrm{rem}$. For the aqueous spray release, the unmitigated onsite dose is greater than 5 rem. The stack is therefore designated as Safety Significant (Safety Class 2) to mitigate this event. WHC safety classification system policy is contained in WHC-CM-1-3, Management Requirements and Procedures, MRP 5.46, "Safety Classification of Systems, Components, and Structures" and WHC-CM-4-46, Chapter 9.0, "Assigning Safety Classes to Systems, Structures, and Components." Additionally, there are no Safety $\mathrm{Cl}$ ass (Safety $\mathrm{Cl}$ ass 1) or Safety Significant (Safety Class 2) systems or components identified for protection of the environment, in accordance with WHC-CM-4-46, Chapter 9.0.

\subsubsection{Summary of Accident Analysis Assumptions}

This section provides a summary of significant assumptions made within the accident analysis. The intent is to facilitate compliance with the safety basis, including screening for USQs, in accordance with DOE Order 5480.21. This section is not intended to impose requirements beyond those already specified or implied elsewhere in the safety basis.

3.2.2.1 Radiological/Toxicological Inventory. The radioactive and chemical inventory assumed in the Accident Analysis will not be exceeded without additional analysis.

$B$ Plant is in a transitional status and would not routinely receive significant additional inventories not previously accounted for in the Accident Analysis. This section is not intended to impose an accounting or 
periodic sampling program to verify the existing bounding inventory within B Plant; instead, it is intended to invoke the USQ process, as necessary. To that end, the following guidance applies.

- New radiological inventory in excess of $1,000 \mathrm{Ci}$ or chemicals received into $B$ Plant will be compared to the chemical and radiological inventories listed in the Accident Analysis to ensure that B Plant remains within the analyzed bounds.

- Quantities of chemicals routinely used for cleaning or maintenance purposes, which are controlled by the industrial safety, hazardous waste or other programs would not require an explicit review.

- Transfer of low-level waste (solid and liquid) from WESF, as described in WHC-SD-WM-TM-004, Rev. 0 (WHC 1994b), has been considered as part of the quantities listed in Table 1-9 and would not require additional review.

This section is related to Sections 2.1.1, "Seismic Events;" 2.2.1, "Release of Radioactive Materials;" 2.2.2, "Release of Nonradioactive Materials;" and 2.3.3.1, "Cell 27 Organic Fire," of the Accident Analysis.

\subsubsection{Emergency Planning for Seismic Event. The Accident Analysis} (Section 2.1.1, "Seismic Events") relies upon actions taken to mitigate a potential hydrogen buildup in the canyon exhaust filters after a seismic event. Such an accident would involve loss of ventilation airflow coincident with flooding of the filter; therefore, B Plant emergency planning will incorporate instructions to respond as necessary to these conditions, which will mitigate potential hydrogen buildup within 30 days.

\subsubsection{Institutional Safety Programs}

Institutional safety programs encompass the policies and procedures instituted by WHC and B Plant Operations to provide additional facility safety and to ensure the safety of the public and facility worker.

In accordance with WHC-CM-4-46, this document addresses the following institutional safety programs, which are found in Table 3-11:

- Safety training

- Radiation protection

- alARA

- Environmental protection

- Emergency planning

- Operations assurance

- Industrial and occupational safety

- Industrial hygiene

- Fire protection

- Hydrogen explosion/deflagration

- Occurrence reporting

- Radioactive hazardous waste management. 
Table 3-11. Administrative and Programmatic Controls. (3 sheets)

\begin{tabular}{|c|c|c|}
\hline $\begin{array}{c}\text { Institutional Safety } \\
\text { Programs }\end{array}$ & Applicable DOE Order(s) ${ }^{\star}$ & Applicable uHC Control led Manual(s) \\
\hline Safety training & $\begin{array}{l}\text { DOE Order } 5480.20, \text { Personnel Selection, Qualification, } \\
\text { Training, and Staffing Reguirements at DoE Reactor and } \\
\text { Nonreactor Muclear Facilities }\end{array}$ & $\begin{array}{l}\text { HSRCM-1, Hanford Site Radiological Control } \\
\text { HHC-CM-1-10, Safety: industrial safety training requirements } \\
\text { HHC-CM-2-15, Iraining Standards: radiological safety training } \\
\text { WHC-IP-1043, ALARA Program: occupational ALARA program (WHC 1995b) } \\
\text { HHC-CM-7-5, Environmental Compliance: environmental training and compliance } \\
\text { verification, } 90 \text { day accumulation area dangerous waste training plan }\end{array}$ \\
\hline Radiation protection & $\begin{array}{l}\text { DOE Order 5400.5, Radiation Protection of the Pubi ic and } \\
\text { Enviroment } \\
\text { DOE Order } 5480.4 \text {, Enviromental Protection, Safety, and } \\
\text { Heal th Protection Standards } \\
\text { DOE Order } 5480.11 \text {, Radiation Protection for Occupational } \\
\text { Horkers } \\
\text { DOE/EH-256T, Radiological control Manual } \\
\text { LOCFR835, Occupational Radiation Protection } \\
\end{array}$ & $\begin{array}{l}\text { HSRCM-1, Hanford Site Radiological Control } \\
\text { WHC-SD-GM-DGS-30011, Radiological Design Guide (WHC 1994C) } \\
\text { WHC-CM-4-16, Dosimetry and Medical Services: external and internal } \\
\text { dosimetry, area monitoring, dosimetry reports and records } \\
\text { WHC-CM-7-5, Environmental Compliance: High Level Waste } \\
\text { WHC-CM-1145, Radiation Protection Progran }\end{array}$ \\
\hline ALARA & $\begin{array}{l}\text { DoE Order } 5480.11 \text {, Radiation Protection for Occupational } \\
\text { Horkers }\end{array}$ & $\begin{array}{l}\text { HSRCM-1, Hanford Site Radiological Control } \\
\text { WHC-CM-1, Company Policies and Charters: ALARA } \\
\text { WHC-CM-1-3, Management Reguirements and Procedures: ALARA } \\
\text { WHC-IP-1043, ALARA Program: ALARA policy and program objective, job } \\
\text { monitoring }\end{array}$ \\
\hline $\begin{array}{l}\text { Enviromental } \\
\text { protection }\end{array}$ & $\begin{array}{l}\text { DOE Order 5400.1, General Environmental Protection } \\
\text { Program } \\
\text { DOE Order 5400.5, Radiation Protection of the Publ ic and } \\
\text { the Enviroment } \\
\text { DOE Order } 5480.4 \text {, Envirommental Protection, Safety, and } \\
\text { Health Protection Standards } \\
\text { DOE Order } 5484.1 \text {, Environmental Protection, Safety, and } \\
\text { Heal th Protection Information Reporting Requirements } \\
\text { RL Order } 91-50, \text { Environmental Monitoring Plan } \\
\text { RL Order } 93-97, \text { Environmental Protection Implementation } \\
\text { PLan }\end{array}$ & 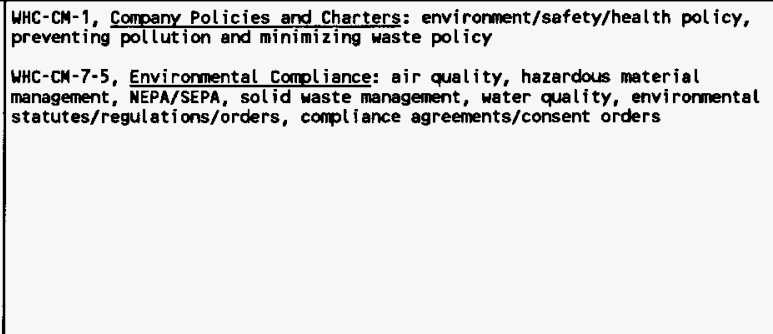 \\
\hline
\end{tabular}


Table 3-11. Administrative and Programmatic Controls. (3 sheets)

\begin{tabular}{|c|c|c|}
\hline $\begin{array}{l}\text { Insti tutional Safety } \\
\text { Programs }\end{array}$ & Applicable DOE Order(s) ${ }^{*}$ & Appl icable WHC Controlled Manual(s) \\
\hline WEmergency plamning & $\begin{array}{l}\text { DOE Order 5500.1B, Emergency Management System } \\
\text { DOE Order 5500.28, Emergency Categories, Classes, and } \\
\text { Notification and Reporting Requirements } \\
\text { DOE Order 5500.3A, Planning and Preparedness for } \\
\text { Operational Emergencies } \\
\text { DOE Order 5500.10, Emergency Readiness Assurance Program }\end{array}$ & $\begin{array}{l}\text { WHC-CM-1-10, Sefety: emergency response guidance } \\
\text { WHC-CM-4-43, Emergency Management Procedures: event command, } \\
\text { reentry/recovery } \\
\text { WHC-CM-4-44, Emergency Preparechess Administration: emergency center } \\
\text { activation }\end{array}$ \\
\hline Operations assurance & $\begin{array}{l}\text { DOE Order } 5480.19 \text {, Conduct of Operations Requirements } \\
\text { for DOE Facilities }\end{array}$ & $\begin{array}{l}\text { WHC-CM-1-3, Management Requirements and Procedures: operations assurance } \\
\text { UHC-CM-1-5, Standard Operating Practices: operational practices }\end{array}$ \\
\hline $\begin{array}{l}\text { Industrial and } \\
\text { occupational safety }\end{array}$ & $\begin{array}{l}\text { DOE Order } 5480.4 \text {, Envirormental Protection, Safety, and } \\
\text { Heal th Protection Standards } \\
\text { DOE Order } 5483.1 \mathrm{~A} \text {, Occupational Safety and Heal th } \\
\text { Program for DoE Contractor Employees at } \\
\text { Government-Owned, Contractor-Cperated Facilities }\end{array}$ & $\begin{array}{l}\text { WHC-CM-1, Company Policies and Charters: enviroment/safety/health policy, } \\
\text { compl iance with safety and environmental requirements } \\
\text { WHC-CM-1-10, Safety: industrial safety/occupational safety } \\
\text { WHC-CM-4-2, Quality Assurance: reduction and reporting of chemical analys is } \\
\text { results }\end{array}$ \\
\hline industrial hygiene & $\begin{array}{l}\text { DOE Order 5480.4, Environmental Protection, Safety, and } \\
\text { Health Protection Standards } \\
\text { DOE Order } 5480.8 \text {, Radiological Health and Safety Policy } \\
\text { DOE Order } 5480.10 \text {, Contractor Industrial Hygiene Program }\end{array}$ & $\begin{array}{l}\text { WHC-CM-1-10, Safety: Industrial Hygiene standards and Guides } \\
\text { WHC-CM-4-40, Industrial Hygiene: industrial hygiene program }\end{array}$ \\
\hline Fire protection & DoE Order $5480.7 \mathrm{~A}$, Fire Protection & $\begin{array}{l}\text { WHC-CM-4-41, Fire Protection Program: fire protection program, fire } \\
\text { protection design, management and acministration, fire protection systems }\end{array}$ \\
\hline $\begin{array}{l}\text { Hydrogen explosion/ } \\
\text { defl agration }\end{array}$ & $\begin{array}{l}\text { DoE Order } 5483.1 \AA \text {, Occlpational Safety and Heal th } \\
\text { Program for DoE Contractor Employees at } \\
\text { Goverment-Owned, Contractor-Operated Facilities } \\
\text { DOE Order } 5480.7 \AA \text {, fire Protection }\end{array}$ & $\begin{array}{l}\text { WHC-CM-1-10, Safety: Industrial Hygiene Standards and Guides } \\
\text { WHC-CM-4-41, Fire Protection Program: fire protection program, fire } \\
\text { protection design, management and administration, fire protection systems }\end{array}$ \\
\hline Occurrence reporting & $\begin{array}{l}\text { Dof Order } 0232.1 \text {, Occurrence Reporting and Processing } \\
\text { of Operations Information }\end{array}$ & $\begin{array}{l}\text { WHC-CM- } 1-4 \text {, Corrective Action Management: lessons learned evaluation } \\
\text { procedure for occurrence reports } \\
\text { WHC-CM- } 1-5 \text {, Standard operating Practices: investigation of and response to } \\
\text { abnormal events and conditions }\end{array}$ \\
\hline
\end{tabular}


Table 3-11. Administrative and Programmatic Controls. (3 sheets)

\begin{tabular}{|c|c|c|}
\hline $\begin{array}{l}\text { Insti tutional Safety } \\
\text { Prograns }\end{array}$ & Applicable DOE Order(s) & Applicable WHC Controlled Manual (s) \\
\hline $\begin{array}{l}\text { Radicact ive and } \\
\text { hazardous waste } \\
\text { managenent }\end{array}$ & $\begin{array}{l}\text { DOE Order 5400.1, General Enviromental Protection } \\
\text { Program } \\
\text { DOE Order 5480.1B, Enviromental Safety and Heal th } \\
\text { Program for DoE. Operations } \\
\text { DOE Order } 5820.2 \mathrm{~A} \text {, Radioactive Waste Management }\end{array}$ & 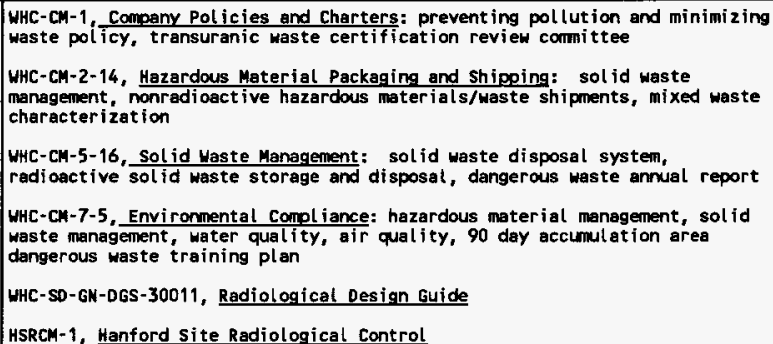 \\
\hline
\end{tabular}

WHC-CM-5-6, B Plant/WESF Iransition Projects Administration, achninisters these WHC administrative and progranmatic requirements and the appl icable DOE requi rements.

W ALARA $=$ As Low as reasonably achievable.

1 DOE = U.S. Department of Energy.

on NEPA = Mational Envi rormental Pol icy Act.

SEPA = State (Washington) Envi rormental Policy Act.

WHC = Westinghouse Hanford Company. 
Table 3-11 also presents administrative and programmatic documentation for these and corresponding DOE Orders and implementation plans.

3.2.3.1 Safety Training. Safety training for the B Plant Complex is incorporated into many of the other facility programs, policies, and procedures. While the majority of the facility-specific aspects of safety training are derived from WHC-CM-5-6, B Plant/WESF Transition Projects Administration, the company-wide or programmatic approach to safety training is documented in the following manuals (Table 3-11):

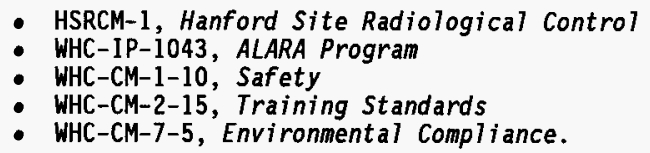

The Maintenance Implementation Plan for B Plant, WHC-SP-0858 (WHC 1993e), identifies the training and qualification requirements of maintenance personnel. Adherence to maintenance procedures is of particular importance because safety equipment is required to mitigate potential accident scenarios and routine maintenance allows for identification and correction of equipment and systems problems that protects personnel. WHC-SP-0858 includes the following:

- Responsibilities

- Maintenance training programs

- Training schedules and support

- On-the-job training

- Qualifications

- Training in root cause analysis

- Training program approval, effectiveness, and feedback

- Management and supervisory training.

3.2.3.2 Radiation Protection. Radiation protection for the public, onsite personnel, and the environment is one of the major concerns at the Hanford Site. DOE Orders 5400.5, Radiation Protection of the PubTic and the Environment; 5480.4, Environmental Protection, Safety, and Health Protection Standards; and 5480.11, Radiation Protection for Occupational Workers, directly address radiation protection, while HSRCM-1, WHC-SD-GN-DGS-30011, (WHC 1994C); WHC-CM-4-16, Dosimetry and Medical Services; and WHC-CM-7-5 address the programmatic approach to this issue (Table 3-11). WHC-CM-5-6, addresses most of the aspects governing B Plant programs, policies, and procedures directly related to radiation protection. One of these programs is as low as reasonably achievable (ALARA). The following topics are part of the B Plant-specific approach to radiation protection, which is discussed in WHC-CM-5-6.

3.2.3.3 As Low as Reasonably Achievable. The ALARA program is applied in all aspects of the $B$ Plant radiation protection program and is a response to DOE Order 5480.11. The ALARA program philosophy is also applied in the material protection program, as part of the overall industrial/occupational safety program. The B Plant ALARA program implements the requirements and procedures defined in HSRCM-1, WHC-CM-1-3, and WHC-IP-1043. WHC-CM-5-6 documents the B Plant-specific ALARA program. This program guides the B Plant team in the 
matters of ALARA awareness and implementation of ALARA practices. The B Plant ALARA program has a set of procedures to address goals, meetings, ALARA management worksheets, and post-ALARA reviews.

The B Plant administration plays a vital role in the successful implementation of the ALARA program. The B Plant manager designates a point of contact for B PIant ALARA program activities.

3.2.3.4 Environmental Protection. A number of DOE Orders specify requirements for environmental protection. These Orders include:

- 5400.5, Radiation Protection of the Public and the Environment

- 5480.1B, Environment Safety, and Health Program

- Order 5480.4, Environmental Protection, Safety, and Health Protection Standards

- Order 5484.1, Environmental Protection, Safety, and Health Protection Information Reporting Requirements.

The WHC programmatic approach to environmental protection is documented in WHC-CM-1, Company Policies and Charters, WHC-CM-1-3, and WHC-CM-7-5. A significant portion of the B Plant environmental protection program is embedded in the facility's waste management programs (Section 3.2.3.12). Some of the existing documents that address B Plant environmental protection issues include:

- B Plant Effluent and Facilities Process Units, WHC-MR-0067 (WHC 1989)

- B Plant Liquid Radioactive Waste Characterization Sampling Plan, WHC-SD-WM-EV-072, Rev 0-A (WHC 1994d)

- B Plant Chemical Sewer Sampling and Analysis Plan, WHC-SD-WM-PLN-029, Rev. 1 (WHC 1992)

- Effluent Monitoring Plan for B Plant Steam Condensate, WHC-SD-EMP-027, Rev. O (WHC 1990C)

- Effluent Monitoring Plan for B Plant Chemical Sewer, WHC-SD-WM-EV-028, Rev. 0 (WHC 1990d)

- Effluent Monitoring Plan for B Plant Cooling Water, WHC-SD-WM-EMP-029, Rev. O (WHC 1990e)

- Effluent Monitoring Plan for B Plant Process Condensate, WHC-SD-EMP-030, Rev. 0 (WHC 1990f)

- Preliminary Safety Evaluation: B Plant Environmental Compliance Upgrades, WHC-SD-W010-PSE-001, Rev. O (WHC 1993f). 
WHC-CM-5-6 documents the procedure for conducting environmental compliance assessments (ECA). The procedure includes responsibilities, requirements, scheduling, conducting ECAs, ECA results, training and qualifications, functions in $B \mathrm{Pl}$ ant to be assessed, and record keeping.

3.2.3.5 Emergency Planning. Emergency planning is required by DOE Orders 5500.1B, Emergency Management System; 5500.2B, Emergency Categories, Classes, and Notification and Reporting Requirements; 5500.3A, Planning and Preparedness for Operational Emergencies; and 5500.10, Emergency Readiness Assurance Program. The WHC programmatic approach to emergency planning is documented in WHC-CM-1-10; WHC-CM-4-43, Emergency Management Procedures; and WHC-CM-4-44, Emergency Preparedness Administration. Emergency Plan for the B Plant Complex, WHC-IP-0263-BPC (WHC 1994e), documents the B Plant-specific emergency plan. The emergency $\mathrm{plan}$ provides employees and visitors information necessary to react to emergency situations in order to do the following:

- Maximize employee safety, minimize risk to life, and provide prompt and efficient treatment for injured persons

- Ensure continuity of leadership at al1 times and in all emergency situations

- Minimize the effects of an accident on the health and safety of the general public and the environment

- Minimize property damage

- Ensure prompt internal and external communications with responsible authority.

The emergency plan addresses building evacuation routes, employee requirements, potential emergency conditions, emergency $p l a n$ implementation, emergency resources, emergency response plans, termination of emergency, accident recovery, post-event analysis, and reporting requirements.

3.2.3.6 Operations Assurance. Operations assurance can be considered a major part of any conduct of operations program. Operations assurance is required by DOE Order 5480.19, Conduct of Operations Requirements for DOE Facilities. WHC-wide operations assurance is documented in WHC-CM-1, and WHC-CM-1-5, Standard Operating Practices, and is applied through WHC-SP-0708, which also documents compliance with DOE Order 5480.19. WHC-CM-5-6 documents the following aspects of operations assurance for the B Plant Complex:

- Administration

- Organizational interface control

- Conduct of operations.

3.2.3.7 Industrial and Occupational Safety. B Plant has numerous industrial and occupational safety programs, policies, and procedures. These requirements are primarily derived from DOE Orders 5480.4 and 5483.1A, Occupational Safety and Health Program DOE Contractor Employees at Government-Owned, Contractor-Operated Facilities. The WHC programmatic 
approach to industrial and occupational safety is documented in $\mathrm{WHC}-\mathrm{CM}-1$, WHC-CM-1-3, WHC-CM-4-2, Quality Assurance, and WHC-CM-1-10.

WHC-CM-5-6 implements policies, plans, and procedures regarding industrial and occupational safety. Other segments of Section 3.2 .3 describe additional programs such as safety training, ALARA, emergency planning, industrial hygiene, fire protection, and radioactive hazardous waste management.

3.2.3.8 Industrial Hygiene. An industrial hygiene program is interrelated with a facility's industrial/occupational safety program and with its radiation protection and radioactive/hazardous waste management programs. DOE Orders 5480.4, 5480.8, Radiological Health and Safety Policy, and 5480.10, Contractor Industrial Hygiene Program, refer to the establishment of an industrial hygiene program, and WHC-CM-1-10 and WHC-CM-4-40, Industrial Hygiene, document the WHC programmatic approach to industrial hygiene. Industrial hygiene is addressed in the B Plant administration manual. The topics addressed include:

- Organizational interface control

- Canyon housekeeping and contamination control

- Chemical spills, water leaks, and condensate leaks

- Safety program

- Hazard communication program.

3.2.3.9 Fire Protection. Fire protection requirements are presented in DOE Order 5480.7A, Fire Protection. Fire Protection at B Plant is addressed on many levels. The company-wide or programmatic approach to fire protection is documented in WHC-CM-4-41, Fire Protection Program.

3.2.3.10 Hydrogen Explosion/Deflagration. An accumulation of radiolytic hydrogen within the plant could represent an explosion/deflagration hazard. As described in the Accident Analysis, this potential is limited primarily to locations where hydrogenous materials, such as water, organic chemicals or ion exchange resins, exist in conjunction with high radiation fields.

For locations where hydrogen rich atmospheres may develop, DOE Order 5483. 1A, DOE Order 5480.7A, WHC-CM-4-3, and WHC-CM-4-41, prescribe measures required to protect against hydrogen explosion or deflagration.

3.2.3.11 0ccurrence Reporting. Occurrence reporting requirements are presented in DOE Order 5000.38, Occurrence Reporting and Processing of Operations Information. Programmatic documentation for occurrence reporting is presented in Table 3-11. Documents that address occurrence reporting include the following:

- WHC-CM-1-3, Management Requirements and Procedures

- WHC-CM-1-4, Corrective Action Management

- WHC-CM-1-5, Standard Operating Practices.

The following B Plant-specific programs are presented in WHC-CM-5-6:

- Occurrence Categorization, Notification, and Reporting

- Conduct of Operations. 
3.2.3.12 Radioactive and Hazardous Waste Management. The handling or management of radioactive and hazardous waste is specified in DOE Order 5400.1, General Environmental Protection Program, DOE Order 5480.1B, and DOE Order 5820.2A, Radioactive Waste Management.

Radioactive and hazardous waste management involves various aspects of environmental protection, radiation protection, ALARA, industrial safety, and occupational safety programs. The WHC-wide programmatic approach to radioactive and hazardous waste management is contained in the following documents:

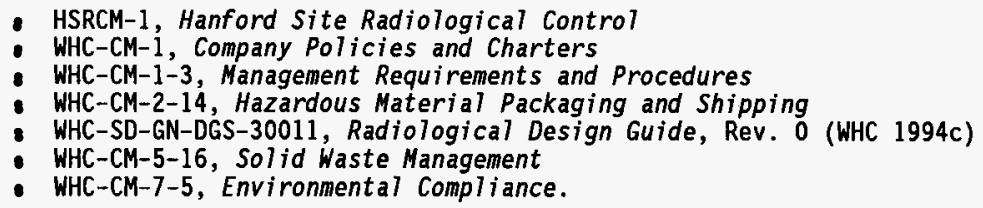

Many radioactive and hazardous waste programs specifically applied at B Plant are presented in WHC-CM-5-6. These programs are described in the manual under the following topics:

- B Plant administration

- Organizational interface control

- Maintenance of waste shipment records

- Conduct of Operations

- Safety program

- Solid waste management

- Controlling lead inventory and use

- Controlling procurement of hazardous material

- Hazard communications program.

Cleanout and Stabilization at B Plant, WHC-SA-1811-FP (WHC 1993g), discusses the following B Plant cleanup issues.

- Canyon work area decontamination

- Radioactive liquid inventory removal

- Systematic equipment deactivation

- HEPA filter inventory stabilization and/or remediation

- Contaminated process equipment and cell characterization

- Residuar facility contamination stabilization

- Decisions required to determine the scope of characterization, disposal of equipment by burial, decontamination activities, and isolation or remediation of significant source terms.

B Plant Waste Minimization Plan, WHC-SD-WM-EV-025, Rev. O-B (WHC 1993h), presents a formalized waste minimization program composed of management 
policies, requirements, and procedures. The plan discusses material use and specifies a review plan at least annually, with revisions made appropriately. This document details the B Plant Waste Minimization Organization's responsibilities, training, employee participation/incentive program, and waste minimization for new projects/designs. The potential for waste identification and minimization is also discussed.

\subsection{INTERIM SAFETY BASIS EVALUATION SUMMARY}

The accident analysis presented in this ISB shows that, with the assistance of safety structures, safety equipment, and institutional safety programs, B Plant is capable of operating within the WHC "offsite" safety envelope described. The accident analysis shows that B Plant is capable of operating within the WHC "onsite" safety envelope described except for the design basis earthquake with the following contributors: organic fire, canyon contamination, filter contamination, and stack collapse on the filter vault. 


\subsection{CONFIGURATION CONTROLS SYSTEM}

This chapter addresses drawing control, operating procedure control, maintenance procedure contro1, modification contro1, USQ procedures, and quality assurance procedures, in accordance with the format and content requirements for ISB documentation in WHC-CM-4-46. Table 4-1 provides the WHC programmatic documentation and DOE Orders that apply to configuration controls systems for configuration management, quality assurance, procedure control, and the USQ process.

\subsection{CONFIGURATION MANAGEMENT}

B Plant-specific programs supporting configuration management are detailed in WHC-CM-5-6. A brief discussion of these programs is contained in the following subsections.

\subsubsection{B Plant Configuration Control and Verification}

The B Plant configuration control and verification program provides the administrative system used to record and verify the condition of, and changes to, B Plant operating facilities to ensure that operations are carried out in a safe and cost-effective manner. The documentation for this program includes responsibilities, requirements, and the program procedure.

\subsubsection{B Plant Facility/Process Monitor and Control System Configuration Control}

The B Plant Facility process monitor and control system configuration control program describes the administrative system used to maintain, modify, and document the configuration of the facility/process monitor and control system. The program provides administrative guidelines for the system key access and control, and includes responsibilities and requirements. The procedure provides guidance for B Plant Engineering, B Plant Maintenance, and B Plant Operations.

\subsubsection{Work Management}

The Work Management Procedure defines how the nine-step process of the job control system described in WHC-CM-1-8, Work Management, is implemented and used in the B Plant Facility. Subjects discussed include the following:

- Modification impact review

- Work change notice

- Construction interfaces

- Work item validation

- Post-work review and documentation. 
Table 4-1. Configuration Control Systems. (2 sheets)

\begin{tabular}{|c|c|c|}
\hline $\begin{array}{l}\text { Configuration } \\
\text { control system }\end{array}$ & Appl icable DOE order & $\begin{array}{c}\text { Appt icable UHC control led manuals } \\
\text { and other programmatic manuals }\end{array}$ \\
\hline $\begin{array}{l}\text { Conf iguration } \\
\text { management }\end{array}$ & $\begin{array}{l}\text { DOE Order 4330.4B, Maintenance Management Program } \\
\text { DOE Order 5480.21, Unreviewed Safety Questions } \\
\text { DOE Order 5480.22, Iechnical Safety Requirements } \\
\text { DOE Order 5480.23, Nuclear Safety Analysis Reports }\end{array}$ & 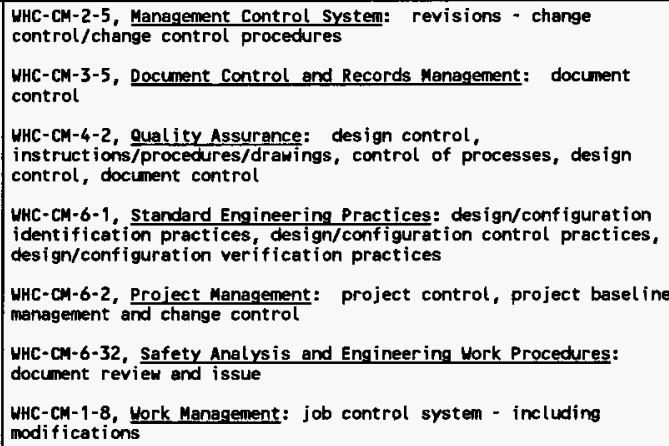 \\
\hline Qual ity assurance & DoE Order 5700.6C, Qual ity Assurance & 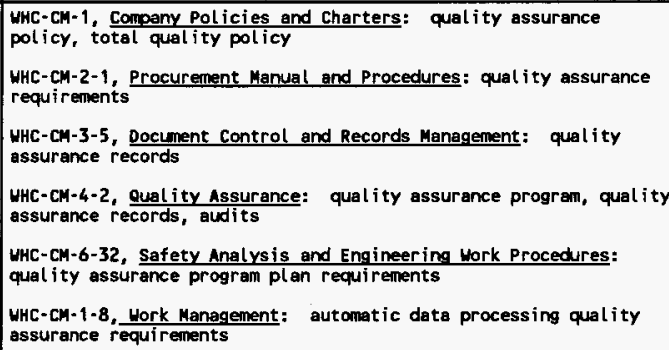 \\
\hline
\end{tabular}


Table 4-1. Configuration Control Systems. (2 sheets)

\begin{tabular}{|c|c|c|}
\hline $\begin{array}{l}\text { Configuration } \\
\text { control system }\end{array}$ & Appl icable DOE order & $\begin{array}{l}\text { Applicable WHC control led manuals } \\
\text { and other programmatic manuals }\end{array}$ \\
\hline Procedure control & $\begin{array}{l}\text { DOE Order } 4330.48 \text {, Maintenance Management Program } \\
\text { DOE Order 5480.19, Conduct of Operations Requirements for } \\
\text { DOE Facilities } \\
\text { DOE-STD-1029-92, Hriter's Guide For Technical Procedures } \\
\text { (DOE 1992b) }\end{array}$ & 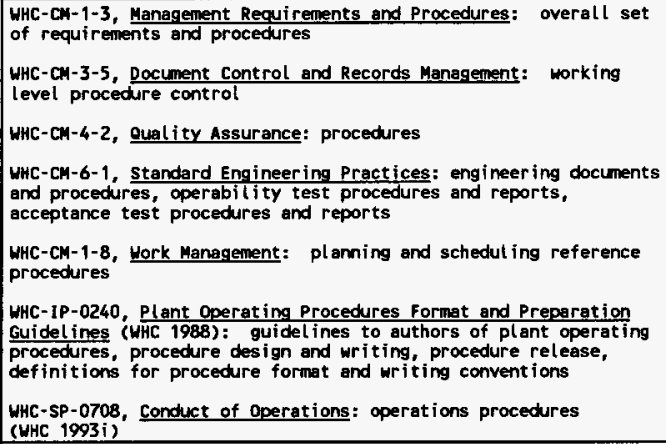 \\
\hline USa process & DOE Order 5480.21, Unreviewed Safety Questions & $\begin{array}{l}\text { WhC-CM-1-3, Management Requirements and Procedures: identifying } \\
\text { and resolving unreviewed safety questions }\end{array}$ \\
\hline
\end{tabular}

DOE = U.S. Department of Energy.

USQ = Unrevieued safety question.

$W H C=$ Westinghouse Hanford Company. 


\subsubsection{Preparing Operating Documents}

Chapter 16 in WHC-IP-1182, B Plant/WESF Conduct of Operations describes the $B \mathrm{Pl}$ ant-specific responsibilities and requirements for preparing operating documents. This preparation is a process consisting of development, review approval, and controlled issue and release.

\subsubsection{B Plant Complex Writer's Guide For Configuration Management}

The B Plant Writer's Guide for Configuration Management provides assistance in recognizing the requirements and guidance provided in DOE Orders and WHC Manuals for preparing most of the documents required at the B Plant Complex. The guide also discusses the responsibilities of B Plant personnel. The guidelines include:

- Document standards

- Identifying the need for a document

- Assigning documentation tasks

- Determining document type

- Preparing document basis

- Agreeing on editing tasks

- Preparing documents

- Reviewing and approving documents' first level of review, verification, validation, approval, first use of a procedure

- Issuing and releasing a document

- Managing records.

\subsubsection{Quality Assurance Program Plan For Configuration Management}

The quality assurance program $\mathrm{plan}$ for configuration management $\mathrm{plan}$ discusses design control, including the requirements and implementation plan, based on the requirements set forth in WHC-CM-4-2 and WHC-CM-6-1, Standard Engineering Practices. The $\mathrm{plan}$ also discusses document control and procurement document control, as part of the overall quality assurance program. The quality assurance program $p l a n$ for the $B$ Plant facility is contained in WHC-CM-5-6. 


\subsubsection{Sitewide Configuration Management}

Table 4-1 provides a list of Sitewide programmatic configuration management system documents and a brief summary of the document contents and associated DOE Orders.

\subsection{QUALITY ASSURANCE}

The B Plant-specific programs supporting quality assurance are detailed in WHC-CM-5-6. Brief descriptions of these programs are contained in the following subsections.

\subsubsection{Work Management}

The quality assurance function, as described in WHC-CM-5-6, is responsible for the review and approval of work packages per MRP 5.43, "Impact Levels," and is responsible for post-review per MRP 5.43. This MRP has been canceled effective 2/1/94 and replaced with WHC-CM-3-5, Document Control and Records Management, MRP 12.7, "Approval of Environmental, Safety, and Quality Affecting Documents."

\subsubsection{B Plant Maintenance}

B Plant Maintenance provides a guide for the administration of B Plant Complex maintenance activities. The quality assurance function, as described in the WHC-CM-5-6, participates in the work authorization process (Section 5.18, "Work Authorization"). In accordance with WHC-CM-4-2, this organization performs normal quality assurance oversight activities.

\subsubsection{Quality Assurance Program Plan}

The quality assurance program plan procedure provides guidance for the implementation of the B Plant quality assurance program plan, as required by WHC-CM-4-2. WHC-CM-4-2 is based on Quality Assurance Program Requirements for Nuclear Facilities, ASME NQA-1-89 (ASME 1989). Over the next three years, WHC will be changing over to compliance with 10 CFR 830.120, "Quality Assurance Rule," Code of Federal Regulations, as amended. The Westinghouse Hanford Company Quality Assurance Program Implementation Plan, WHC-SP-1131, (WHC 1995C), has been developed for this procedure. The B Plant quality assurance program plan discusses the following topics:

- General requirements

- Quality assurance program implementation

- Design control requirements and implementation

- Procurement document control

- Instructions procedures drawings

- Document control

- Purchased material, equipment, and services control

- Identification and control of items

- Process control 
- Inspection

- Test controls

- Control of measuring and test equipment

- Handling, storage, and shipping

- Determination of inspection, testing, and operating statuses

- Nonconforming items control

- Corrective action

- Records maintenance

- Audit performance.

\subsubsection{Sitewide Quality Assurance}

Table 4-1 provides a 1 ist of Sitewide programmatic quality assurance documentation and a brief summary of the document contents and associated DOE orders.

\subsection{PROCEDURE CONTROL}

The B Plant-specific programs supporting quality assurance are detailed in WHC-CM-5-6. Brief descriptions of the programs are contained in the following subsections.

\subsubsection{Review of New, Revised, and Procedure Change Authorized Modified Procedures}

The review of modified procedures establishes the system necessary to ensure that B Plant Operations personnel are aware of new and revised procedures and procedure change authorizations affecting $B$ Plant facilities.

\subsubsection{Policy and Procedure Review}

The Policy and Procedure Review ensures that appropriate B Plant Operations staff are aware of new and revised WHC policies and procedures and provides a method for documenting B Plant Operations staff review of such policies and procedures.

\subsubsection{Preparing Operating Documents}

The Preparing Operating Documents Procedure provides guidelines for the preparation of plant operating procedures, temporary and one-time procedures, and work procedures and work plans.

\subsubsection{Conduct of Operations}

The conduct of operations program includes compliance by operations, conditions when not to follow procedures along with alternate guidance, what 
WHC-SD-WM-ISB-008 REV 0

to do in the case of procedural inadequacy during emergencies, procedure implementation, procedure sign-off 1 ist, and periodic review of operating procedures.

\subsubsection{Quality Assurance Program Plan For Procedure Control}

The quality assurance program $p l$ an for procedure control addresses the requirements and implementation of instructions, procedures, and drawings.

\subsubsection{B Plant Complex Writer's Guide For Procedure Control}

Chapter 16 in WHC-IP-1182, B P1 ant/WESF Conduct of Operations provides assistance in document preparation and procedures. The guide assigns responsibilities and provides guidelines. Guidelines include document preparation and document review, including validation and verification, and document approval. The guide also provides guidance for the first use of a procedure.

\subsubsection{Sitewide Procedure Control}

Table 4-l provides a list of Sitewide programmatic procedural control system documentation and a brief summary of the document contents and associated DOE Orders.

\subsection{UNREVIEWED SAFETY QUESTION PROCESS}

The B Plant-specific program supporting the USQ process is detailed in WHC-CM-5-6 and describes the B Plant-specific requirements for implementing WHC-CM-1-3, MRP 5.12 "Identifying and Resolving Unreviewed Safety Questions." The $B \mathrm{Pl}$ ant USQ process program also addresses the responsibilities, requirements, and procedures associated with the process. It also defines the processes of ensuring that the USQ review is based on a valid safety basis, screening and evaluating a proposed change, and screening and evaluating occurrences.

\subsubsection{Sitewide Unreviewed Safety Question Requirement}

Table 4-1 provides the Sitewide USQ requirement, and a brief summary of the procedure contents and associated DOE Order. 
WHC-SD-WM-ISB-008 REV 0

This page intentionally left blank.

4-8 


\subsection{REFERENCES}

\subsection{CODES AND REgULATIONS}

ASME, 1989, Quality Assurance Program Requirements for Nuclear Facilities, ASME NQA-1-89, American Society of Mechanical Engineers, New York, New York.

SDC-4.1, 1989, Standard Architectural-Civil Design Criteria: Design Loads for Facilities, Rev. 11, Hanford Plant Standards, Westinghouse Hanford Company, Richland, Washington.

UBC, 1940, Uniform Building Code, International Conference of Building officials, Whittier, California.

10 CFR 830.120, "Quality Assurance Rule," Code of Federal Regulations, as amended.

\subsection{DOCUMENTS}

Blume, John A., 1971, Earthquake Analysis of the Waste Encapsulation Facility, JABE-VITRO-01, John A. Blume and Associates, San Francisco, California.

Conrad, T. J., and G. R. Wagenblast, 1989, AR Vault, AR Stack, and B Plant Stack Seismic Evaluation, (Internal Letter SA:GRW: 89-15, to

R. J. Murkowski), Westinghouse Hanford Company, Richland, Washington.

ICF KEH, 1991, B Plant Filter Design Calculations, ICF KEH, Richland, Washington.

LLNL, 1980, Design and Evaluation Guidelines for Department of Energy Facilities Subjected to Natural Phenomena Hazards, UCRL-15910, Lawrence Livermore National Laboratory, Livermore, California.

WHC, 1983, B Plant Support Facilities Natural Forces Evaluation, WHC-SD-WM-TA-002, Rev. 0, Rockwell Hanford Operations, Hanford, Washington.

WHC, 1988, Plant Operating Procedure Format and Preparation Guidelines, WHC-IP-0240, Westinghouse Hanford Company, Richland, Washington.

WHC, 1989, B Plant Effluent and Facilities Process Units, WHC-MR-0067, Westinghouse Hanford Company, Richland, Washington.

WHC, 1990a, B Plant Canyon Structure Seismic Evaluation Review Documentation, WHC-SD-WM-SA-007, Rev. 0, Westinghouse Hanford Company, Richland, Washington.

WHC, 1990b, Not Used. 
WHC, 1990c, Effluent Monitoring Plan for B Plant Steam Condensate, WHC-SD-WM-EMP-027, Rev. 0, Westinghouse Hanford Company, Richland, Washington.

WHC, 1990d, Effluent Monitoring Plan for B Plant Chemical Sewer, WHC-SD-WM-EMP-028, Rev. 0, Westinghouse Hanford Company, Richland, Washington.

WHC, 1990e, Effluent Monitoring Plan for B Plant Cooling Water, WHC-SD-WM-EMP-029, Rev. 0, Westinghouse Hanford Company, Richland, Washington.

WHC, 1990f, Effluent Monitoring Plan for B Plant Process Condensate, WHC-SD-WM-EMP-030, Rev. 0, Westinghouse Hanford Company, Richland, Washington.

WHC, 1991a, B Plant Structural Qualification Interim Report, WHC-SD-WM-SA-001, Rev. 0, Westinghouse Hanford Company, Richland, Washington.

WHC, 1991b, B Plant Canyon Structure Seismic Evaluation, WHC-SD-WM-SA-005, Rev. 0, Westinghouse Hanford Company, Richland, Washington.

WHC, 1991c, B Plant Building Interface Study, WHC-SD-WM-SA-014, Rev. 0, Westinghouse Hanford Company, Richland, Washington.

WHC, 1991d, B Plant Confinement Study, WHC-SD-WM-SA-012, Rev. 0, Westinghouse Hanford Company, Richland, Washington.

WHC, 1991e, B P7ant Cell Drain Header Seismic Analysis, WHC-SD-W024H-SA-001, Rev. 0, Westinghouse Hanford Company, Richland, Washington.

WHC, 1991f, B Plant Canyon Exhaust Ductwork and Filter Study, WHC-SD-WM-SA-016, Rev. 0, Westinghouse Hanford Company, Richland, Washington.

WHC, 1992, B Plant Chemical Sewer Sampling and Analysis Plan, WHC-SD-WM-PLN-029, Rev. 1, Westinghouse Hanford Company, Richland, Washington.

WHC, 1993a, B P7ant Safety Analysis Report, WHC-SD-WM-SAR-013, Rev. 2, Westinghouse Hanford Company, Richland, Washington.

WHC, 1993b, B Plant Preliminary Hazards Analysis, WHC-SD-WM-PHA-008, Rev. 0, Westinghouse Hanford Company, Richland, Washington.

WHC, 1993C, B Plant Seismic Qualification of E-Filter, WHC-SD-W239-SA-001, Westinghouse Hanford Company, Richland, Washington.

WHC, 1993d, Preliminary Safety Analysis Report, B Plant Environmental Compliance Upgrades, 211-B Chemical Tank Farm and 221-B Gallery Scale Tanks, WHC-SD-WO1OH-PSAR-001, Rev. 0, Westinghouse Hanford Company, Richl and, Washington. 
WHC, 1993e, Maintenance Implementation Plan for B Plant, WHC-SP-0858, Rev. 1, Westinghouse Hanford Company, Richland, Washington.

WHC, 1993f, Preliminary Safety Evaluation: B Plant Environmental Compliance Upgrades Project WO1OH, WHC-SD-W010-PSE-001, Rev. 0, Westinghouse Hanford Company, Richland, Washington.

WHC, 1993g, Cleanout and Stabilization at B Plant, WHC-SA-1811-FP, Westinghouse Hanford Company, Richland, Washington.

WHC, 1993h, B Plant Waste Minimization Plan, WHC-SD-WM-EV-025, Rev. 0-B, Westinghouse Hanford Company, Richland, Washington.

WHC, 1993i, Westinghouse Hanford Company Conduct of Operations - GOCO Cross Cultivation, WHC-SP-0708, Westinghouse Hanford Company, Rich1and, Washington.

WHC, 1994a, B Plant Cleanout and Stabilization Program Update, WHC-SD-WM-PRS-014, Rev. 0, Westinghouse Hanford Company, Richland, Washington.

WHC, 1994b, B Plant Facility Description, WHC-SD-WM-TM-004, Rev. 0, Westinghouse Hanford Company, Richland, Washington.

WHC, 1994c, Radiological Design Guide, WHC-SD-GN-DGS-30011, Rev. 0, Westinghouse Hanford Company, Richland, Washington.

WHC, 1994d, B Plant Liquid Radioactive Waste Characterization Sampling Plan, WHC-SD-WM-EV-072, Rev. 0-A, West inghouse Hanford Company, Richland, Washington.

WHC, 1994e, Emergency Plan for the B Plant Complex, WHC-IP-0263-BPC, Rev. 4, Westinghouse Hanford Company, Richland, Washington.

WHC, 1995a, B Plant Canyon End-Wall Study, WHC-SD-WM-SA-013, Rev. 0, Westinghouse Hanford Company, Richland, Washington.

WHC, 1995b, Westinghouse Hanford Company Occupational ALARA Program, WHC-IP-1043, Rev. 0, Westinghouse Hanford Company, Richland, Washington.

WHC, 1995c, The Westinghouse Hanford Company Quality Assurance Program and Implementation P7an, WHC-SP-1131, Westinghouse Hanford Company, Richland, Washington.

WHC, 1996a, B Plant Interim Safety Basis Accident Analysis, WHC-SD-WM-SARR-030, Rev. 0, Westinghouse Hanford Company, Richland, Washington.

WHC, 1996b, B Plant Building Interface Study, WHC-SD-WM-SA-014, Rev. 0, Westinghouse Hanford Company, Richland, Washington.

WHC, 1996c, B Plant Confinement Study, WHC-SD-WM-SA-012, Rev. 0, Westinghouse Hanford Company, Richland, Washington. 
WHC, 1996d, B Plant Canyon Exhaust Ductwork and Filter Study, WHC-SD-WM-SA-016 Rev. 0, Westinghouse Hanford Company, Richland, Washington.

\subsection{WESTINGHOUSE HANFORD COMPANY CONTROLLED MANUALS}

HSRCM-1, Hanford Site Radiological Control, Westinghouse Hanford Company, Richland, Washington.

WHC-CM-1, Policies And Charters, Westinghouse Hanford Company, Richl and, Washington.

WHC-CM-1-3, Management Requirements and Procedures, Westinghouse Hanford Company, Richland, Washington.

WHC-CM-1-4, Corrective Action Management, Westinghouse Hanford Company, Richland, Washington.

WHC-CM-1-5, Standard Operating Practices, Westinghouse Hanford Company, Richland, Washington.

WHC-CM-1-8, Work Management, Westinghouse Hanford Company, Richland, Washington.

WHC-CM-1-10, Safety, Westinghouse Hanford Company, Richland, Washington.

WHC-CM-2-1, Procurement Manual and Procedures, Westinghouse Hanford Company, Richland, Washington.

WHC-CM-2-5, Management Control System, Westinghouse Hanford Company, Richland, Washington.

WHC-CM-2-14, Hazardous Material Packaging and Shipping, Westinghouse Hanford Company, Richland, Washington.

WHC-CM-2-15, Training Standards, Westinghouse Hanford Company, Richland, Washington.

WHC-CM-3-5, Document Control and Records Management, Westinghouse Hanford Company, Richl and, Washington.

WHC-CM-4-2, Quality Assurance, Westinghouse Hanford Company, Richland, Washington.

WHC-CM-4-16, Dosimetry and Medical Services, Westinghouse Hanford Company, Richland, Washington.

WHC-CM-4-40, Industrial Hygiene, Westinghouse Hanford Company, Richland, Washington.

WHC-CM-4-41, Fire Protection Program, Westinghouse Hanford Company, Richland, Washington. 
WHC-CM-4-43, Emergency Management Procedures, Westinghouse Hanford Company, Richland, Washington.

WHC-CM-4-44, Emergency Preparedness Administration, Westinghouse Hanford Company, Richland, Washington.

WHC-CM-4-46, Nonreactor Facility Safety Analysis, Westinghouse Hanford Company, Richland, Washington.

WHC-CM-5-6, B Plant/WESF Transition Projects Administration, Westinghouse Hanford Company, Richland, Washington.

WHC-CM-5-16, Solid Waste Management, Westinghouse Hanford Company, Richland, Washington.

WHC-CM-6-1, Standard Engineering Practices, Westinghouse Hanford Company, Richl and, Washington.

WHC-CM-6-2, Project Management, Westinghouse Hanford Company, Richl and, Washington.

WHC-CM-6-32, Safety Analysis and Engineering Work Procedures, Westinghouse Hanford Company, Richland, Washington.

WHC-CM-7-5, Environmental Compliance, Westinghouse Hanford Company, Richl and, Washington.

\subsection{U.S. DEPARTMENT OF ENERGY ORDERS}

DOE, 1992a, Hazard Categorization and Accident Analysis Techniques for Compliance with DOE Order 5480.23, Nuclear Safety Analysis Reports, DOE-STD-1027-92, U.S. Department of Energy, Washington, D.C.

DOE, 1992b, Writer's Guide for Technical Procedures, D0E-STD-1029-92, U.S. Department of Energy, Washington, D.C.

DOE 0 231.1, Occurance Reporting and Processing of Operations Information, U.S. Department of Energy, Washington, D.C.

DOE Order 4330.4B, Maintenance Management Program, U.S. Department of Energy, Washington, D.C.

DOE Order 5000.3B, Occurrence Reporting and Processing of Operations Information, U.S. Department of Energy, Washington, D.C.

DOE Order 5400.1, General Environmental Protection Program, U.S. Department of Energy, Washington, D.C.

DOE Order 5400.5, Radiation Protection of the Public and Environment, U.S. Department of Energy, Washington, D.C.

DOE Order 5480.1B, Environmental Safety and Health Program for DOE Operations, U.S. Department of Energy, Washington, D.C. 
DOE Order 5480.4, Environmental Protection, Safety, and Health Protection Standards, U.S. Department of Energy, Washington, D.C.

DOE Order 5480.7A, Fire Protection, U.S. Department of Energy, Washington, D.C.

DOE Order 5480.8, Radiological Health and Safety Policy, U.S. Department of Energy, Washington, D.C.

DOE Order 5480.10, Contractor Industrial Hygiene Program, U.S. Department of Energy, Washington, D.C.

DOE Order 5480.11, Radiation Protection for Occupational Workers, U.S. Department of Energy, Washington, D.C.

DOE Order 5480.19, Conduct of Operations Requirements for DOE Facilities, U.S. Department of Energy, Washington, D.C.

DOE Order 5480.20, Personnel Selection, Qualification, Training, and Staffing Requirements at DOE Reactor and Nonreactor Nuclear Facilities, U.S. Department of Energy, Washington, D.C.

DOE Order 5480.21, Unreviewed Safety Questions, U.S. Department of Energy, Washington, D.C.

DOE Order 5480.22, Technical Safety Requirements, U.S. Department of Energy, Washington, D.C.

DOE Order 5480.23, Nuclear Safety Analysis Reports, U.S. Department of Energy, Washington, D.C.

DOE Order 5483.1A, Occupational Safety and Health Program for DOE Contractor Employees at Government-Owned, Contractor-Operated Facilities, U.S. Department of Energy, Washington, D.C.

DOE Order 5484.1, Environmental Protection, Safety, and Health Protection Information Reporting Requirements, U.S. Department of Energy, Washington, D.C.

DOE Order 5500.1B, Emergency Management System, U.S. Department of Energy, Washington, D.C.

DOE Order 5500.2B, Emergency Categories, Classes, and Notification and Reporting Requirements, U.S. Department of Energy, Washington, D.C.

DOE Order 5500.3A, Planning and Preparedness for Operational Emergencies, U.S. Department of Energy, Washington, D.C.

DOE Order 5500.10, Emergency Readiness Assurance Program, U.S. Department of Energy, Washington, D.C.

DOE Order 5700.6C, Quality Assurance, U.S. Department of Energy, Washington, D.C. 
DOE Order 5820.2A, Radioactive Waste Management, U.S. Department of Energy, Washington, D.C.

DOE Order 6430.1A, General Design Criteria, U.S. Department of Energy, Washington, D.C.

RL Order 91-50, Environmental Monitoring Plan, U.S. Department of Energy, Richland Operations office, Richland, Washington.

RL Order 93-97, Environmental Protection Implementation, U.S. Department of Energy, Richland Operations Office, Richland, Washington. 
WHC-SD-WM-ISB-008 REV 0

This page intentionally left blank.

$5-8$ 
WHC-SD-WM-ISB-008 REV 0

\subsection{ACKNOWLEDGEMENTS}

The authors would like to acknowledge the following for their contributions to this document.

- K. S. McCu11ough, Hazard Categorization

- S. E. Chalk, ISB Rewrite/Update

- B. A. Schwehr, Assistance in Plant Configuration Corrections 
WHC-SD-WM-ISB-008 REV 0

This page intentionally left blank. 
WHC-SD-WM-ISB-008 REV O

APPENDIX A

HAZARD CATEgORIZATION

REPORT FOR B PLANT

A-1 
WHC-SD-WM-ISB-008 REV 0

This page intentionally left blank. 


\subsection{INTRODUCTION}

This Appendix provides the hazard categorization analysis of the B Plant Facility, as required by DOE Order 5480.23, Nuclear Safety Analysis Reports and DOE-STD-1027-92, Hazard Categorization and Accident Analysis Techniques for Compliance with DOE Order 5480.23 (DOE 1992). The hazard category identified for a facility provides the basis for determining the level of detail in the facility safety analysis documentation and the methodologies to be applied in the accident analysis process.

B Plant is located in the northwest corner of the 200 East Area at the Hanford Site. The B Plant was originally designed to chemically process spent nuclear fuels. The last process mission was completed in 1985. Presently, the B Plant Facility is not operating and has been placed in a cleanout and stabilization program. The new mission is to complete a transition to long-term surveillance and maintenance in preparation for D\&D. Details of the cleanout and stabilization activities are provided in cleanout and Stabilization Program Update, WHC-SD-WM-PRS-014, Rev. 0 (WHC 1994a).

During the transition to shutdown, several systems must remain operational to support WESF and its radioactive strontium and cesium capsule inventory. B Plant supplies cooling water and deionized water for pool cells and accepts low-level liquid waste streams, liquid effluents, and solid waste from WESF. Systems supporting the WESF operations have been included in the analysis.

B Plant is a complex of several buildings and support buildings. B Plant Facility Description, WHC-SD-WM-TM-004, Rev. 0 (WHC 1994b), provides more detail of the B Plant facilities. As a result of the cleanout and stabilization activities, the radiological material inventory in the plant has been significantly reduced. The radiologically contaminated systems, structures and components remaining within the B Plant Complex and considered in this hazard categorization analysis include the following:

- 221-B, B Plant Main Facility

- Tank TK-9-1, low-level waste storage

- Tank TK-10-1, low-1evel waste storage

- Tank TK-24-1, low-level waste storage

- Tank TK-26-1, aqueous storage

- Tank TK-27-3, organic solvent storage

- Tank TK-27-4, ICF pump (currently not in use: residual contamination)

- Tank TK-28-3, organic solvent storage

- Tank TK-28-4, IBF pump $R$ (currently not in use: residual contamination) 
- Tank TK-29-2, supernatant receiver (currently not in use: residual contamination)

- Tank TK-30-3, aqueous storage

- Tank TK-36-1, flush water

- Tank TK-39-1, low-level waste storage

- Cells 4 and 22, Process Cells

- Canyon structure and miscellaneous equipment

- 291-B, Sand Filter Building

- Sand Filter

- 291-BD, Filter Building

- A filter

- B filter

- C filter

- D filter

- 212-B Cask Transfer Facility.

\subsection{RADIOLOGICAL HAZARD CATEGORIZATION ANALYSIS}

Based on the results of the radiological hazard categorization analysis described in the following sections, the B Plant Facility is classified as a Hazard Category 2 nuclear facility.

\subsection{METHODOLOGY}

The B Plant Facility hazard categorization was performed using the methodology provided in DOE-STD-1027-92. DOE-STD-1027-92 requires categorization of a facility based on total curies per radionuclide located in the facility. The hazard categorization is identified by determining the ratio of the total quantity of each specific facility radionuclide to the Hazard Category 2 threshold quantities for the identical radionuclide provided in DOE-STD-1027-92. Once the individual isotopic ratios are established, the ratio quantities are summed. If the total of the ratios exceeds one, then the facility is classified a Hazard Category 2 nuclear facility.

\subsection{RADIOLOGICAL HAZARD CATEGORIZATION ANALYSIS}

The radiological issotopes of consequence for the $B$ Plant have been identified as ${ }^{90} \mathrm{Sr}$ and ${ }^{137} \mathrm{Cs}$ and ${ }^{239} \mathrm{Pu}$. The $\mathrm{B} \mathrm{Pl}$ ant radiological inventory is provided in Table A-1. The total $B$ Plant inventory for ${ }^{90} \mathrm{Sr}$ is $562,401 \mathrm{C}$; 
the total inventory for ${ }^{137} \mathrm{CS}$ is $1,246,716 \mathrm{Ci}$ and the total inventory for ${ }^{239} \mathrm{Pu}$ is $0.93 \mathrm{Ci}$.

Table A-1. B Plant Radiological Inventory.

\begin{tabular}{|c|c|c|c|}
\hline System & Ci of ${ }^{90} \mathrm{Sr}$ & Ci of ${ }^{137} \mathrm{Cs}$ & $\left\{\xi_{9 \mathrm{Pu}}^{\text {of }}\right.$ \\
\hline Tank TK-26-1 (a) & 22,891 & 992 & $\mathrm{n} / \mathrm{a}$ \\
\hline Iank TK-27-3(a) & 2,112 & 1,456 & $n / a$ \\
\hline Tank TK-28-3(a) & 3,346 & 1,473 & $n / a$ \\
\hline Tank TK-30-3(a) & 21,802 & 945 & $n / a$ \\
\hline Tank TK-36-1 $(b)$ & & 3,000 & $n / a$ \\
\hline $\begin{array}{l}\text { Tanks TK-9-1, TK-10-1, (b) } \\
\text { TK-22-1, TK-24-1, TK-29-2, } \\
\text { TK-39-1 }\end{array}$ & 1,250 & 850 & \\
\hline A filter ${ }^{(b)}$ & 12,000 & 18,000 & 0.062 \\
\hline B filter ${ }^{(b)}$ & 29,000 & 43,000 & 0.062 \\
\hline c filter ${ }^{(b)}$ & 16,000 & 25,000 & 0.062 \\
\hline D filter $(b)$ & 50,000 & 550,000 & 0.062 \\
\hline Sand filter $\langle b\rangle$ & 3,000 & 2,000 & 0.682 \\
\hline $\begin{array}{l}\text { Canyon structure and } \\
\text { miscel laneous equipment (b) }\end{array}$ & 400,000 & 600,000 & \\
\hline $212-B^{(b)}$ & 1,000 & $n / a$ & $n / a$ \\
\hline Total & 562,401 & $1,246,716$ & $0.93^{239} \mathrm{Pu}$ \\
\hline
\end{tabular}

capacity

(a) Derived from Table 2-17, WHC-WM-SD-SARR-030, Rev. 0 (WHC 1995), with $80 \%$ tank

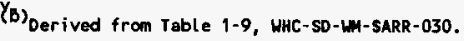

The ratio of plant inventory curies to the Hazard Category 2 threshold curie provided in DOE-STD-1027-92 are calculated and totaled in Table A-2. As noted in the table, the summed ratios total $3.94 \times 10^{1}$, which is greater than 1; therefore, B Plant is classified as a Hazard Category 2 nuclear facility and is considered to have significant onsite dose consequences. 
Table A-2. B Plant Category Determination.

\begin{tabular}{|c|c|c|c|}
\hline Isotope & $\begin{array}{c}\text { B Plant } \\
\text { inventory curie }\end{array}$ & $\begin{array}{c}\text { Hazard Category 2 } \\
\text { threshold curie }\end{array}$ & $\begin{array}{c}\text { Ratio of facility } \\
\text { inventory to Hazard } \\
\text { Category 2 }\end{array}$ \\
\hline${ }^{N} \mathrm{Sr}$ & 562,401 & 22,000 & 25.56 \\
\hline $239 \mathrm{Pu}$ & 0.93 & $56\left(5.6 \times 10^{4}\right)$ & 0.02 \\
\hline $131 \mathrm{Cs}$ & $1,246,716$ & $89,000\left(8.9 \times 10^{4}\right)$ & 14.01 \\
\hline Total of Ratios & & 39.59 or \\
\hline
\end{tabular}

According to DOE-STD-1027-92, the application of the graded approach to the facility-specific accident analysis is determined by the hazard category of the facility. In turn, the level of detail in the safety analysis report must support the methodology and level of detail provided in the accident analysis. Consequently, the B Plant Accident Analysis (WHC 1995) should use the methodology identified in DOE-STD-1027-92 for Hazard Category 2 nuclear facilities.

\subsection{REFERENCES}

DOE Order 5480.23, Nuclear Safety Analysis Reports, U.S. Department of Energy, Washington, D.C.

DOE, 1992, Hazard Categorization and Accident Analysis Techniques for Compliance with DOE Order 5480.23, Nuclear Safety Analysis Reports, DOE-STD-1027-92, U.S. Department of Energy, Washington, D.C.

WHC, 1994a, B Plant Cleanout and Stabilization Program Update, WHC-SD-WM-PRS-014, Rev. 0, West inghouse Hanford Company, Richland, Washington.

WHC, 1994b, B Plant Facility Description, WHC-SD-WM-TM-004, Rev. 0, Westinghouse Hanford Company, Richland, Washington.

WHC, 1995, B Plant Interim Safety Basis Accident Analysis, WHC-SD-WM-SARR-030, Rev. 0 , Westinghouse Hanford Company, Richland, Washington. 


\section{Department of Energy \\ Richland Operations Office \\ P.O. $80 \times 550$}

Richland, Washington 99352

\section{OCT 251996}

$96-$ TPD -226

Mr. H. J. Hatch, President

Fluor Daniel Hanford, Inc

Richland, Washington

Dear Mr. Hatch:

\begin{tabular}{|c|c|}
\hline Post-it' Fax Nole & \begin{tabular}{|l|l|l|l|l} 
Dale $/ 0 / 30 / 96$ & poges \\
\end{tabular} \\
\hline To AUROAA $A A U$ & From laue RuEGC \\
\hline Coldepe Fonas & CO. BUHC \\
\hline Prone: & Phone 372.0443 \\
\hline Fax: $372-0629$ & Fax \\
\hline
\end{tabular}

APPROVAL OF B PLANT SAFETY EVALUATION REPORT - BASIS FOR INTERIM OPERATION (CONTRACT DE-ACO6-96RL13200)

The enclosed Safety Evaluation Report (SER) presents the results of an RL review of the proposed Basis for Interim Operation (BIO) for B Plant. The SER states that the operation of B Plant, as described in the proposed BIO and within the conditions established. in the SER, can be performed without undue risk to the public, the environment, and onsite and facility workers.

The following documents comprise the proposed B Plant BIO: WHC-SD-WM-TM-004, Rev 1, B Plant Facility Description, WHC-SD-HM-ISB-008, Rev 0, 8 Plant Interim Safety Basis, and WHC-SD-WM-SARR-030, Rev O, B Plant. Interim Safety Basis Accident Analysis.

It is RL's understanding that the 810 is intended to supersede the existing $B$ Plant Safety Analysis Report WHC-SD-WM-SAR-013 and the 212B Hazards

Identification and Evaluation Report WHC-SD-WM-SAR-008. The existing B Plant SARs and their associated OSRs will remain in effect until FDH has developed and executed an implementation plan for the BIO.

FOH is directed to notify the RL Manager when implementation has been completed. FDH is further directed to formally request deletion of the $B$ Plant Safety Analysis Reports and their associated OSRs when the BIO implementation is complete.

If you have any questions, please contact me or your staff may contact David T. Evans, B Plant Program Manager, on 373-9278.

TPD:DTE

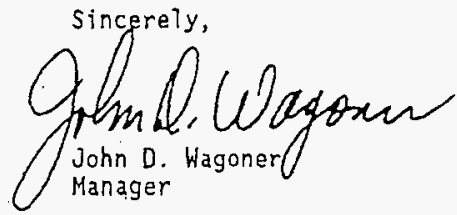

Enclosure

cc w/encl:

L. Olguin, FDH R. E. Heineman, BWHC

G. Reddick, FDH . P. E. Roege, BWHC

H. F. Heer, BWHC K. A. Beecher, GSSC 


\section{DISTRIBUTION SHEET}

\begin{tabular}{|c|c|c|c|c|c|c|}
\hline \multirow{2}{*}{$\begin{array}{l}\text { To } \\
\text { Distribution }\end{array}$} & \multirow{2}{*}{\multicolumn{4}{|c|}{$\begin{array}{l}\text { From } \\
\text { S. E. Chalk }\end{array}$}} & \multicolumn{2}{|c|}{ Page 1 of 1} \\
\hline & & & & & \multicolumn{2}{|c|}{ Date $11 / 7 / 96$} \\
\hline \multirow{2}{*}{\multicolumn{4}{|c|}{$\begin{array}{l}\text { Project Title/Work Order } \\
\text { B Plant Interim Safety Basis/KN24F }\end{array}$}} & & \multirow{2}{*}{\multicolumn{2}{|c|}{$\begin{array}{ll}\text { EDT No. } & 600058 \\
\text { ECN No. } & \text { N/A } \\
\end{array}$}} \\
\hline & & & & & & \\
\hline \multicolumn{2}{|l|}{ Name } & MSIN & $\begin{array}{l}\text { Text } \\
\text { With All } \\
\text { Attach. }\end{array}$ & Text Only & $\begin{array}{l}\text { Attach./ } \\
\text { Appendix } \\
\text { Only }\end{array}$ & $\begin{array}{c}\text { EDT/ECN } \\
\text { Only }\end{array}$ \\
\hline \multicolumn{2}{|c|}{$\begin{array}{l}\text { S. E. Chalk } \\
\text { L. I. Covey } \\
\text { D. W. Craig } \\
\text { E. N. Dodd, Jr. } \\
\text { D. T. Evans (4 copies) } \\
\text { B. J. Gray. } \\
\text { R. E. Heineman } \\
\text { L. E. Johnson } \\
\text { S. E. Killoy } \\
\text { G. L. McCormick } \\
\text { A. B. Rau (2 copies) } \\
\text { P. E. Roege ( } 5 \text { copies) } \\
\text { D. K. Smith } \\
\text { M. K. Ullah } \\
\text { Central Files (2 copies + originals) } \\
\text { Docket Files (2 copies) }\end{array}$} & $\begin{array}{l}\text { A2-25 } \\
\text { S6-51 } \\
\text { S6-81 } \\
\text { S7-12 } \\
\text { T1-98 } \\
\text { S6-81 } \\
\text { S6-65 } \\
\text { A2-25 } \\
\text { S4-66 } \\
\text { H5-31 } \\
\text { A2-25 } \\
\text { S4-66 } \\
\text { S6-81 } \\
\text { S6-69 } \\
\text { A3-88 } \\
\text { B1-17 }\end{array}$ & $\begin{array}{l}x \\
x \\
x \\
x \\
x \\
x \\
x \\
x \\
x \\
x \\
x \\
x \\
x \\
x \\
x \\
x\end{array}$ & & & \\
\hline
\end{tabular}

